\title{
THE EFFECTS OF TEMPERATURE AND OF TISSUE PRES- SURE ON THE MOVEMENT OF FLUID THROUGH THE HUMAN CAPILLARY WALL
}

\author{
By EUGENE M. LANDIS and JOHN H. GIBBON, JR. \\ (From the Robinette Foundation of the Hospital of the University of Pennsylvania, \\ Philadelphia)
}

(Received for publication August 15, 1932)

The various physical factors concerned in transporting fluid through the human capillary wall have received relatively little attention in spite of the value that such information might have in clarifying the complicated mechanism of fluid balance and the even more involved mechanism of edema formation. The present lack of information is to be ascribed, in all probability, to the difficulty of obtaining quantitative data concerning the filtration and absorption of small amounts of tissue fluid. At present the plethysmograph offers the only available means of detecting small changes in the volume of extravascular fluid.

The ordinary plethysmograph was found by Krogh, Landis and Turner (1) to be quite unsuitable for measuring the volume of tissue fluid accumulating during short periods of slight or moderate venous congestion. Therefore, a so-called "pressure plethysmograph" was devised to exclude spontaneous variations in arm volume referable to changing vasomotor tone. Pressure was exerted on the surface of the segment of forearm within the plethysmograph in order to collapse the blood vessels before the final volume was measured. Under these conditions the state of contraction or dilatation of the blood vessels did not, within certain limits, interfere with the reasonably accurate measurement of changes in the volume of tissue fluid.

It was found in normal subjects that fluid was filtered into the tissues of the forearm when the venous pressure exceeded $15 \mathrm{~cm}$. water. Above an average venous pressure of $17 \mathrm{~cm}$. water the rate of filtration was directly proportional to the increase in venous pressure. When the subject stood motionless the colloid osmotic pressure of the blood rose and the rate of filtration produced by given grades of venous congestion fell. Thus changes in capillary pressure and in the colloid osmotic pressure of the blood influenced the movement of fluid through the capillary walls of normal human subjects in a manner conforming to the Starling hypothesis.

If capillary blood pressure and the colloid osmotic pressure of the blood were the sole factors involved in fluid balance it would be difficult to explain how it is possible for the human being to avoid dependent 
edema whenever the erect posture is assumed. The observations reported in this paper are concerned with two additional factors which modify conspicuously the rate at which fluid is filtered through the capillary wall. It will be shown that the presence of fluid in the tissue spaces diminishes or even abolishes the filtration ordinarily produced by low grades of venous congestion. It seems probable, therefore, that fluid accumulating in the tissue spaces develops a tissue pressure which retards filtration and reduces the further loss of fluid from the blood stream.

In an effort to diminish the variability in measurements of filtration rates the effects of temperature were studied. In extending the studies of Drury and Jones (2) it was found that the rate of filtration depends on the temperature of the forearm even when low venous pressures, well within the physiological range, are used.

\section{APPARATUS}

The "pressure plethysmograph" used in these observations operated on the same general principles as the one devised by Krogh, Landis and Turner (1). It was modified, however, so that each determination of "reduced arm volume" (i.e. tissue volume with the blood vessels collapsed) required only two minutes. This was accomplished $(a)$ by fixing both the plethysmograph and forearm to a heavy iron base, $(b)$ by substituting rigid aluminium diaphragms for the rubber ends of the earlier apparatus, and $(c)$ by using a pressure of $200 \mathrm{~mm} . \mathrm{Hg}$ (instead of $55 \mathrm{~cm}$. water) to compress the segment of forearm within the plethysmograph. In addition, by equipping the apparatus with a double wall, the temperature of the plethysmograph and of the water contained within it could be maintained approximately constant throughout each observation.

The plethysmograph, shown in Figure $1 A$, was made of brass, $0.5 \mathrm{~mm}$. in thickness, shaped in the form of a double-walled truncated cone, having a length of $16 \mathrm{~cm}$. The inside diameter at the upper end was $9 \mathrm{~cm}$., at the lower end $11 \mathrm{~cm}$. The inner wall $(I)$ was separated from the outer $(O)$ by a distance of $0.5 \mathrm{~cm}$., making a closed chamber through which water from a 20 -liter reservoir was circulated by a small centrifugal pump expelling 6 liters per minute. This prevented the water inside the plethysmograph from gaining or losing heat from the air, and kept the apparatus at a relatively constant temperature.

A sleeve $(S)$ of thin rubber, $0.25 \mathrm{~mm}$. in thickness, $36 \mathrm{~cm}$. long, and 8 and $10 \mathrm{~cm}$. in diameter at the ends, was placed inside the metal case. The ends of this rubber sleeve were everted and attached firmly $\left(S^{\prime}\right)$ to the ends of the plethysmograph. The rubber was cemented to the metal, contact being maintained by stretching a band of rubber, $1 \mathrm{~cm}$. wide and $2 \mathrm{~mm}$. thick, over the ends of the sleeve and the plethysmograph. An adjustable metal hoop, $1 \mathrm{~cm}$. in width, encircled each end of the sleeve with its rubber band. To avoid complicating the diagram in Figure $1 A$, neither the rubber nor the metal bands are shown. The rubber sleeve was made large enough so that when collapsed it extended about $4 \mathrm{~cm}$. beyond the ends of the plethysmograph; when filled with water under pressure the sleeve lay against the arm in a series of folds $(F)$.

Each end of the plethysmograph was closed by three aluminium diaphragms (D), $0.5 \mathrm{~mm}$. thick, $14 \mathrm{~cm}$. wide and $14 \mathrm{~cm}$. long, shaped as shown in Figure $1 B$, which represents an end view of the apparatus. The inner edge of each diaphragm was cut out, leaving a semicircular space to accommodate the forearm. 
With a set of such diaphragms, having openings varying between 4 and $10 \mathrm{~cm}$. in diameter, forearms of different sizes and shapes could be fitted accurately enough to keep the thin rubber sleeve, even while distended, inside the plethysmograph. The diaphragms were held in place by brackets $(B)$ attached to each end of the plethysmograph. A thick rubber washer $(W)$ was placed between the diaphragms and the end of the plethysmograph to prevent the thin rubber sleeve from being cut by the sharp edges of the diaphragms. The central part of this washer consisted of a sheet of thin rubber dam $(D A)$ with a central opening having a diameter slightly smaller than the corresponding segment of forearm. This prevented the inner bag from escaping through any small space left between the edges of the metal diaphragms and the skin. Each diaphragm was slotted $(S L)$ so that it could be moved inward, or rotated, on the screw $(S C)$ until it was in gentle contact with the skin of the forearm. The aluminium diaphragms, when thus adjusted, were fastened tightly against the rubber washer and the end of the plethysmograph by screwing a heavy brass ring $(R), 3 \mathrm{~mm}$. in thickness, against the three brackets. This prevented the relatively thin aluminium diaphragms from bulging when the pressure inside the plethysmograph was raised.

The large opening into the center of the plethysmograph was closed by a rubber stopper $(R U)$ which contained a glass tube $(T)$. Pressure tubing connected this glass tube with the burette $(B U)$ through the double-walled glass bulb $(B L)$. The space between the inner wall of the plethysmograph $(I)$ and the thin rubber sleeve $(S)$, the glass bulb $(B L)$, the burette $(B U)$ and the pressure tubing were all filled with water as shown in Figure $1 C$. The temperature of the water in the plethysmograph was measured by means of a thermal junction inserted to the very tip of the glass tube $(G)$ which extended about $2 \mathrm{~cm}$. beyond the inner surface of the rubber stopper.

During each determination of "reduced arm volume" over $100 \mathrm{cc}$. of water moved from the burette $(B U)$ into the plethysmograph. To prevent the temperature of the water in the plethysmograph from fluctuating, the doublewalled glass bulb $(B L)$ was inserted between the plethysmograph and the burette. The inner chamber of this double-walled bulb had a capacity of 275 cc. and communicated with the burette and the inside of the plethysmograph. Water from the reservoir and pump passed through the outer chamber of the bulb, thence to the space between the inner and outer walls of the plethysmograph and finally back to the reservoir. Thus the bulb and the plethysmograph were kept at the same temperature, and whenever "reduced arm volume" was determined, the water moving from the burette displaced water at a constant temperature from the inner bulb into the plethysmograph.

The burette was of the ordinary $100 \mathrm{cc}$. size with graduations of $0.1 \mathrm{cc}$. A larger tube, having a capacity of $100 \mathrm{cc}$. and a length of $30 \mathrm{~cm}$., was fused to the upper end of the burette and calibrated in centimeters. The total volume of this modified burette was $200 \mathrm{cc}$; the calibrations were so arranged that changes in total arm volume were read in units of $1.0 \mathrm{cc}$. (see protocol 1) while "reduced arm volumes" were read in units of $0.1 \mathrm{cc}$. The upper end of the burette communicated through a "Y" tube either with room air or with a 40liter reservoir containing air under a pressure of $200 \mathrm{~mm}$. $\mathrm{Hg}$.

Venous pressure was elevated by inflating a pneumatic cuff, $50 \mathrm{~cm}$. long and $15 \mathrm{~cm}$. wide, which encircled the arm just above the elbow. 


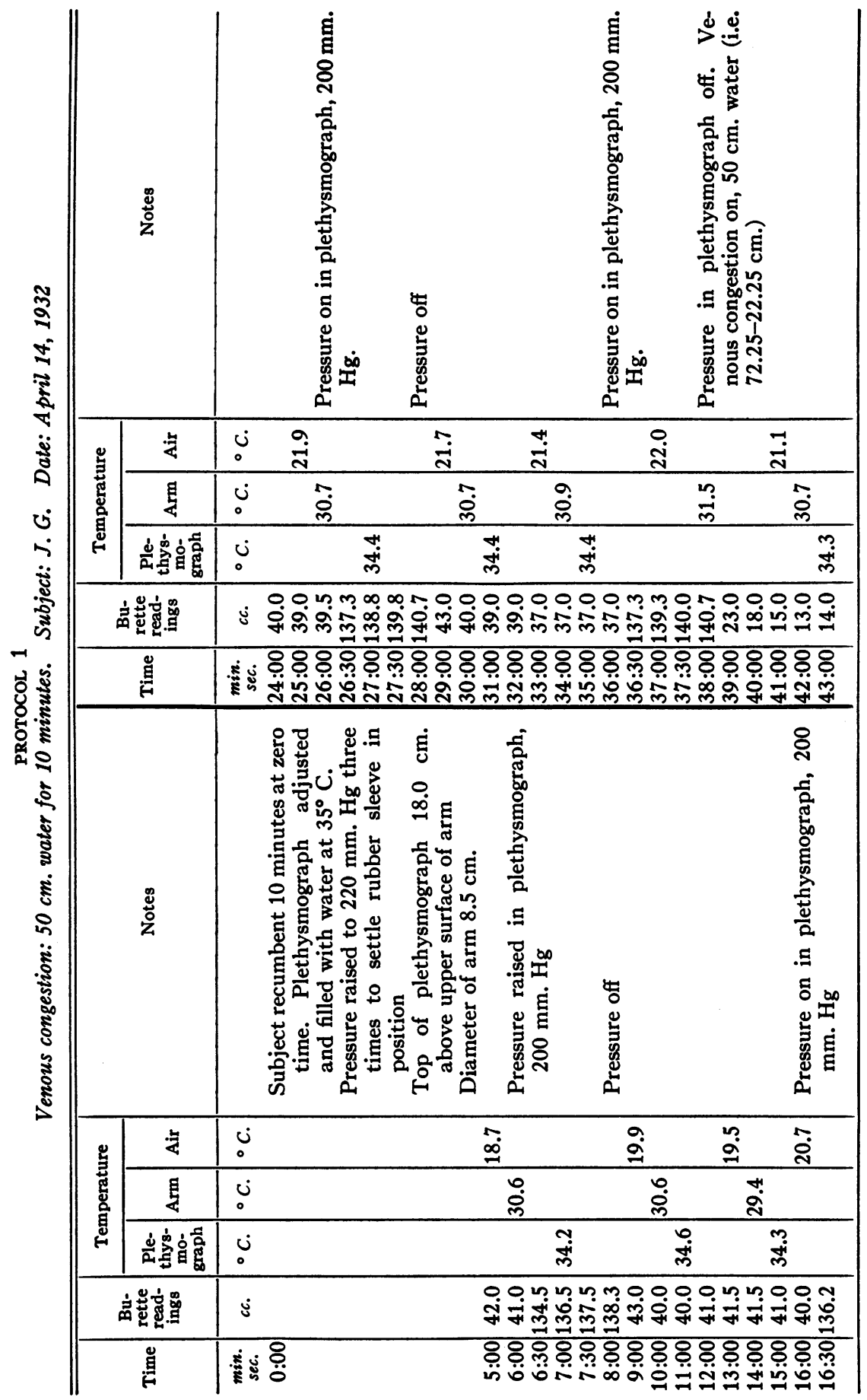




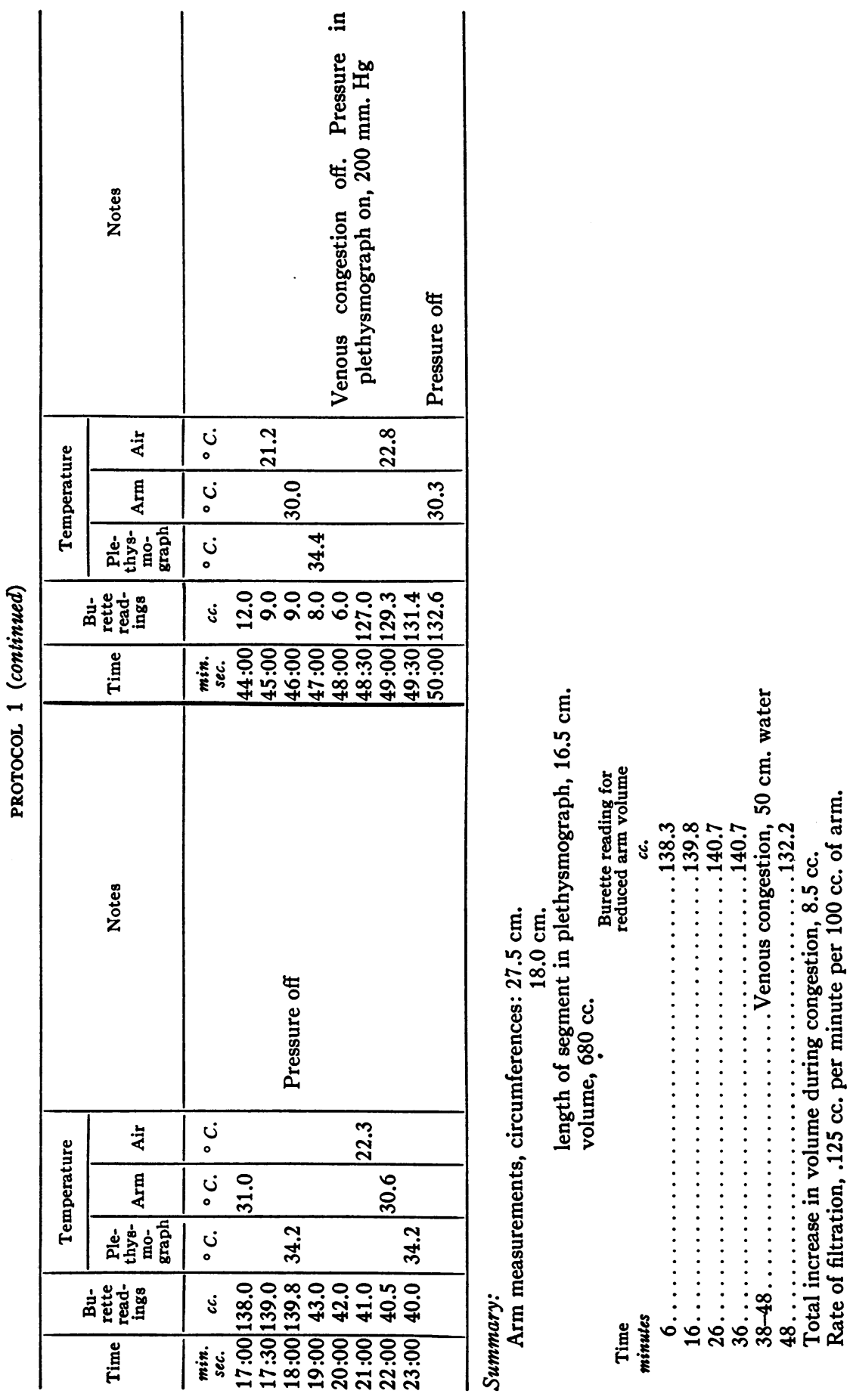


METHOD

The burette-plethysmograph system was first partially filled with water and any air bubbles that had accumulated were removed. The pump was started and water at the desired temperature $(14.5,24.5,34.5$ or $44.5^{\circ} \mathrm{C}$.) was circulated through the outer portions of the plethysmograph and of the glass bulb.

In all of the observations described here the subjects were in the recumbent position. The arm was abducted and the elbow was flexed at right angles to the upper arm, with the forearm extending vertically. The posterior surface of the arm rested on the base of the heavy iron standard as shown in Figure 1A. In this position the iron base prevented
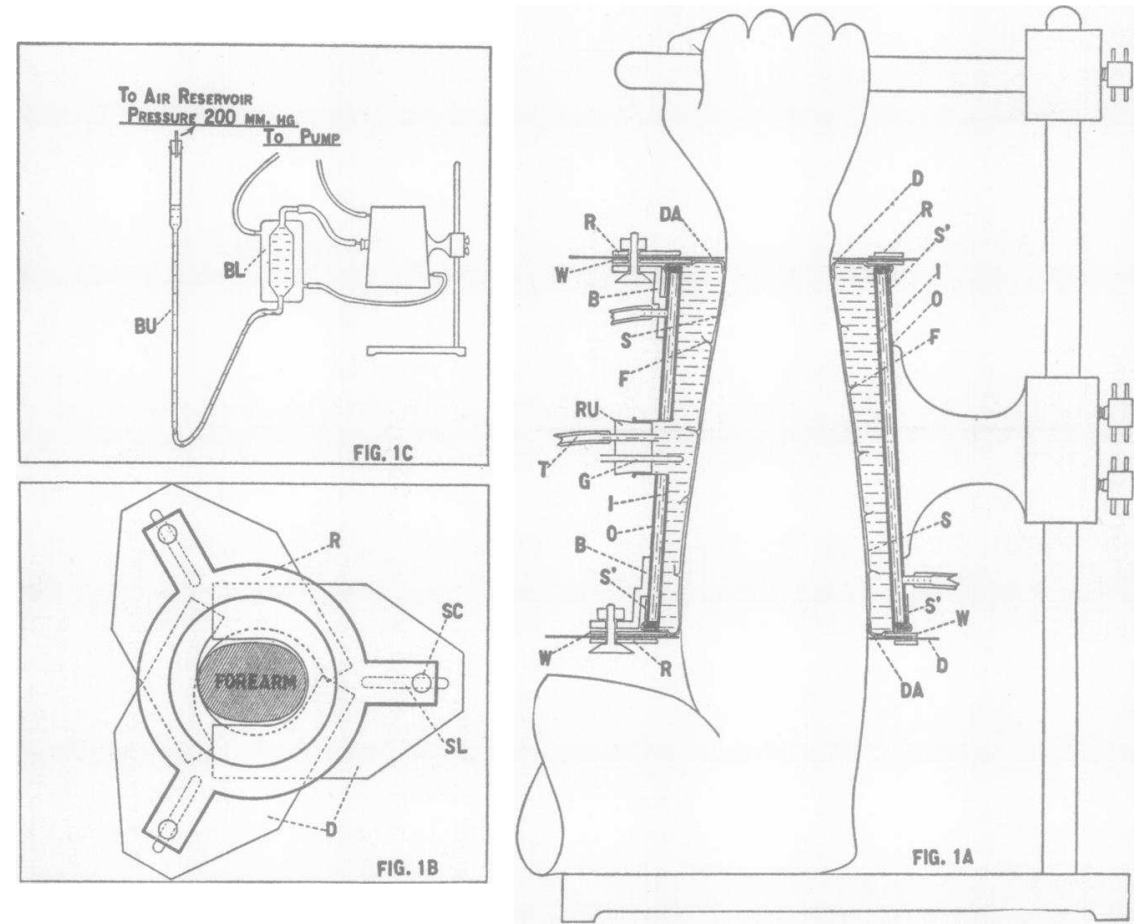

Fig. 1A. Diagram of the Pressure Plethysmograph, Forearm, and

For description see text.

\section{STANDARD}

Fig. 1B. Diagram Showing an End View of the Plethysmograph with the Three Diaphragms and Heavy Brass Ring

Fig. 1C. Diagram Showing the Arrangement of the Burette, DoubleWalled Bulb and the Plethysmograph

the forearm from moving with reference to the plethysmograph even when the pressure was raised to $200 \mathrm{~mm}$. $\mathrm{Hg}$. The plethysmograph, with the inner sleeve collapsed, was lowered over the forearm and adjusted so that its midpoint was level with the manubrium sterni. The 
fingers were lightly flexed over a horizontal bar clamped to the standard and fixed with adhesive tape. The aluminium diaphragms were then moved against the forearm and firmly clamped in place.

The position of the arm in relation to the plethysmograph was only relatively secure. It was necessary for the subject to remain absolutely still if reliable readings were to be obtained. Therefore every effort was made to have the subject entirely comfortable before an experiment began. It was usually inadvisable to prolong the duration of an observation beyond two hours because after that time increasing discomfort in the region of the elbow sometimes made the subject restless.

With the forearm in position water at the chosen temperature (14.5, $24.5,34.5$ or $44.5^{\circ} \mathrm{C}$.) was poured into the burette. As the plethysmograph filled, the thin rubber sleeve was pushed against the skin and diaphragms by water displaced from the glass bulb. The burette was filled almost completely; and its upper end was then connected to the "Y" tube with the limb leading to room air open, and the limb leading to the reservoir containing air at a pressure of $200 \mathrm{~mm}$. $\mathrm{Hg}$ closed.

The surface of the water in the burette was always kept level with the upper edge of the plethysmograph (see Figure 1C). The volume of water in the burette-plethysmograph system remained unchanged throughout each experiment so that whenever the volume of the arm decreased, the surface of the water in the burette fell below the point of reference-i.e. the upper end of the plethysmograph. The burette was then raised to return the surface of the water to this level and, pressure thus being constant, the volume change could be read directly from the burette. When arm volume decreased, the burette reading in cubic centimeters became higher; when arm volume increased, the burette reading in centimeters became lower, by an amount equal to the change in arm volume.

The term "reduced arm volume" will be used in the same sense described before by Krogh, Landis and Turner (1); it refers to the volume of the segment of forearm in the plethysmograph when the blood vessels are collapsed by external pressure.

Protocol 1, representing a typical experiment, shows the procedure used in measuring the volume of fluid filtered in ten minutes by a venous pressure of $50 \mathrm{~cm}$. water. The surface temperature of the forearm outside the plethysmograph was measured by means of a thermal junction placed against the skin midway between the lower edge of the plethysmograph and the elbow. These readings, recorded in Protocol 1 and Table 1 under "Arm temperature," indicate the skin temperature in those portions of the forearm which were exposed to the air. "Plethysmograph temperature" refers to the water surrounding the segment of forearm within the plethysmograph. Air temperature was measured by means of a third thermal junction near the forearm. 
After the arm had been properly adjusted in the plethysmograph readings of arm volume were begun on the fifth minute, the top of the burette being open to the air. On the sixth minute the burette was placed in communication with the 40-liter reservoir containing air at a pressure of $200 \mathrm{~mm} . \mathrm{Hg}$. Water passed rapidly from the burette into the plethysmograph, the burette reading changing from 41.0 to $134.5 \mathrm{cc}$. during the first 30 seconds. As water was forced out of the burette into the plethysmograph the burette was slowly raised in its holder so that the surface of the water was always level with the upper edge of the plethysmograph. During the first 5 to 10 seconds after pressure was raised the subject experienced throbbing in the forearm but as soon as sufficient water had entered the plethysmograph to elevate the pressure above systolic blood pressure this sensation disappeared. The blood expressed from the collapsed blood vessels of the forearm could leave through the open veins proximal to the plethysmograph.

The change in volume observed during the first 30 seconds of the pressure period usually amounted to between 80 and $110 \mathrm{cc}$., the exact figure depending chiefly on the temperature of the forearm. Part of this change, about $35 \mathrm{cc}$., was due to stretching of the rubber tubing, to readjustments of the folds in the rubber sleeve, and to slight bulging of the ends of the plethysmograph. During the second period of 30 seconds the change in volume usually amounted to about $2 \mathrm{cc}$., during the third period of 30 seconds to $1.0 \mathrm{cc}$. and during the fourth period of 30 seconds to between 0.4 and $0.9 \mathrm{cc}$. Only the final reading, obtained after the pressure had been applied for 2 minutes, was used in calculations, but readings were made at intervals of 30 seconds to be certain that the change in volume during compression was quite regular. Very occasionally involuntary movements of the muscles of the forearm invalidated a determination of "reduced arm volume," a condition made evident by irregular changes in volume during the period when pressure was applied.

After circulation had been occluded for 2 minutes the rubber tube between the compressed air reservoir and the top of the burette was clamped off, the burette being placed once more in communication with room air. Water left the plethysmograph and the burette readings changed rapidly to the previous values, varying, in Protocol 1, between 40 and $43 \mathrm{cc}$. After a rest period of 8 minutes (at times only 3 minutes) the determination of "reduced arm volume" was repeated, for comparison with the first reading. During the control period this procedure was repeated until the readings of "reduced arm volume" became relatively constant.

It was usual, as shown in Protocol 1, for the second reading of "reduced arm volume" to be lower than the first by 1.0 to $2.0 \mathrm{cc}$. The difference between successive readings became less and less and finally two successive 
readings commonly differed by less than $0.9 \mathrm{cc}$. The control period was prolonged until this was the case in order that the measurement of filtration might not involve large errors due to conspicuous changes in the original "reduced arm volume."

In the experiment shown in Protocol 1 the third and fourth determinations of "reduced arm volume" were the same. At the end of the last control determination (thirty-eighth minute) the pressure in the plethysmograph was released and simultaneously the armlet was inflated to elevate venous pressure in the forearm to $50 \mathrm{~cm}$. water.

To raise venous pressure in the vertically placed forearm to a given figure, the pressure in the pneumatic cuff encircling the upper arm must be greater by the hydrostatic pressure of the column of blood in the vertical veins of the forearm. The segment of forearm within the plethysmograph was supported by water externally so that the effective venous pressure in the forearm enclosed by the plethysmograph was that existing at the upper surface of the plethysmograph. Thus to elevate venous pressure in the segment of forearm within the plethysmograph to $50 \mathrm{~cm}$. water required that the pressure in the veins of the upper arm be $50 \mathrm{~cm}$. water plus the hydrostatic pressure of the column of blood extending from the level of the upper arm veins to the top of the plethysmograph.

In the experiment described in Protocol 1, the top of the plethysmograph was $18 \mathrm{~cm}$. above the upper surface of the arm. The diameter of the arm was $8.5 \mathrm{~cm}$. The large veins are situated near the middle of the arm so that the correction was computed by adding to $18.0 \mathrm{~cm}$. half the diameter of the upper arm $(4.25 \mathrm{~cm}$.), making a total correction figure of $22.25 \mathrm{~cm}$. Thus, to produce a venous pressure of $50 \mathrm{~cm}$. water in the forearm required that the pressure in the pneumatic cuff on the upper arm be elevated to $72.25 \mathrm{~cm}$. water.

This correction figure, determined separately for each observation, was always between 22 and $23 \mathrm{~cm}$. water. The approximate accuracy of this correction was verified further in certain instances by determining the cuff pressure which produced the first measurable engorgement of the veins in the plethysmograph. Changes in total arm volume were followed while the armlet was inflated successively to 10,15,20,25, 27.5 and $30 \mathrm{~cm}$. water pressure. It was necessary to elevate the armlet pressure to between 25 and $27.5 \mathrm{~cm}$. before engorgement of the veins could be detected in the readings of total arm volume. To measure venous pressure by capsular methods proved to be impossible when the forearm was in the vertical position. The need for this correction figure, when the forearm is vertically placed, makes it unwise to draw too definite conclusions involving absolute venous pressures. It does not affect conclusions based on the comparative effects of various venous pressures or of one venous pressure over long periods of time. Hereafter, only the effective venous pressure in the forearm segment will be mentioned, the 
corresponding armlet pressure being always greater by between 22 and $23 \mathrm{~cm}$. water.

The venous pressure used in the experiment recorded in Protocol 1 was $50 \mathrm{~cm}$. water, the congestion being continued for 10 minutes. The cuff pressure was then released, and three seconds later the pressure in the plethysmograph was again elevated to $200 \mathrm{~mm}$. $\mathrm{Hg}$. The "reduced arm volume" was $132.2 \mathrm{cc}$., which, by comparison with the previous reading of 140.7 , indicated that tissue volume was $8.5 \mathrm{cc}$. greater as a result of congestion.

The apparatus was then removed and the volume of the segment of forearm enclosed by the plethysmograph was determined according to the method previously described (1). The rate of filtration at a given venous pressure was computed by dividing the change in "reduced arm volume" by the duration of the congestion and by the volume of the segment. Filtration rate was always expressed in terms of cc. of fluid filtered per minute per $100 \mathrm{cc}$. of arm. Where volume changes alone were considered they were recorded in terms of cc. of fluid per $100 \mathrm{cc}$. of arm.

\section{OBSERVATIONS}

The studies reported in this paper were made on two male subjects (J. G. and E. L.) with normal blood pressures. A few experiments were repeated, using other normal subjects; the results were identical with those to be described. All filtration rates were determined after the subject had been recumbent for at least 30 minutes.

A number of control experiments were made in order to determine the limitations of the apparatus and method. It is obvious that the accuracy with which change in volume was measured depended upon (a) the uniform distensibility of the apparatus (including rubber tubing, the ends of the apparatus, etc.) during repeated periods of elevated pressure, (b) the uniformity with which the rubber sleeve applied itself to the surface of the forearm in repeated periods of elevated pressure, and $(c)$ the fixation of the arm relative to the plethysmograph.

The first two points were tested by determining "reduced arm volume" at intervals of 5 and 10 minutes using a wooden model of the forearm. When pressure was raised to $200 \mathrm{~mm}$. $\mathrm{Hg}$ approximately $35 \mathrm{cc}$. of water left the burette; this change was due chiefly to closer application of the rubber bag to the forearm, stretching of the rubber tubing, and to slight bulging of the diaphragms at the ends of the plethysmograph. Repeated readings of "reduced arm volume," each made at the end of the usual two-minute pressure period, were practically constant. Thus in one experiment 6 determinations made during 54 minutes were 59.7, $59.8,59.8,59.8,59.8,59.8 \mathrm{cc}$. In a second experiment 6 determinations made during 51 minutes were 44.0, 44.0, 44.0, 44.0, 44.0 and $44.1 \mathrm{cc}$. These observations made on a wooden model of the forearm, under 
conditions otherwise identical with those obtaining during studies on the human subject, show that the elastic parts of the apparatus distended equally in successive determinations and that, with a pressure of $200 \mathrm{~mm}$. $\mathrm{Hg}$, the thin rubber sleeve was applied to the surface of the forearm with great accuracy.

Nevertheless, whenever a series of readings of "reduced arm volume" were made with the forearm in the plethysmograph the successive values as indicated in Protocol 1 showed a definite tendency to fall off. As observed previously (1), this tendency is greater with the first one or two readings becoming less in later readings. When the readings were made at intervals of five or ten minutes the first two or three readings usually differed by from 0.8 to $2.0 \mathrm{cc}$., always indicating an apparent decrease in arm volume. After the first three or four readings, however, the decrease in "reduced arm volume" rarely amounted to more, and was usually less, than $0.9 \mathrm{cc}$. for a segment of forearm having a volume of approximately $700 \mathrm{cc}$. This slow apparent decrease in "reduced arm volume" continued as long as the determinations were made. It was possibly due to the high pressure used, although similar changes in "reduced arm volume" were observed with the much lower pressure used in the earlier method (1). Moreover, "reduced arm volume" decreased slowly when readings were made at intervals of five, ten or twenty minutes. Certain comparative experiments, described below, indicate that the amount of tissue fluid expressed from the segment of forearm within the plethysmograph by a two-minute period at $200 \mathrm{~mm}$. $\mathrm{Hg}$ must be relatively small.

It is also possible $(a)$ that placing the forearm in the vertical position may lead to a slow progressive readjustment of the equilibrium between tissue fluid and blood, or (b) that the forearm cannot be fixed in position as rigidly as the wooden model. In an effort to obtain constant readings in control observations numerous expedients were tried without success. In any case, the apparent decrease in volume during the latter part of each control period amounted usually to less than 0.015 , and rarely to more than 0.020 , cc. per minute per $100 \mathrm{cc}$. of arm. This change was small in comparison to the filtration rates observed at venous pressures above $20 \mathrm{~cm}$. water, and introduced little error in the comparative studies reported here. The higher pressure and the vertical position of the forearm could not be avoided since it was essential that readings be made repeatedly at short intervals.

By using a high pressure in the plethysmograph the circulation could be stopped in the forearm itself. This left the veins of the arm open and the amount of blood which could be conducted away from the compressed forearm was not limited. When the armlet was inflated for one minute prior to the determination of "reduced arm volume" the amount of blood imprisoned in the veins within the plethysmograph might be as much as 30 to $40 \mathrm{cc}$. Nevertheless, although the determination of "reduced arm 
volume" began even within two or three seconds after the release of congestion the final reading at the end of two minutes' compression varied by only a few tenths of a cc. from the control readings made when the "reduced arm volume" was determined with previously undistended veins. This indicated that the escape of blood from the forearm was quite complete. Additional evidence of the relatively complete removal of blood by the pressure of $200 \mathrm{~mm}$. $\mathrm{Hg}$ may be found in Figure 5 .

\section{$(A)$. The relationship between venous pressure and the rate of filtration at 34 to $35^{\circ} \mathrm{C}$.}

These observations were carried out in two ways. In the first series of observations after the subject had been recumbent for at least 30 minutes and after two successive readings of "reduced arm volume" had agreed within $0.9 \mathrm{cc}$. or less, the venous pressure was elevated to 20,30 , 40,60 or $80 \mathrm{~cm}$. water for a period of 30 minutes. At the end of the thirtieth minute the venous congestion was released and immediately thereafter the pressure within the plethysmograph was elevated to 200 $\mathrm{mm}$. Hg. The burette reading at the end of two minutes was compared with the reading taken under similar conditions immediately before the period of congestion. The temperature of the plethysmograph was maintained between 34 to $35^{\circ} \mathrm{C}$. throughout the control and experimental periods.

The results of the series of determinations after 30-minute periods of congestion are shown in Figure 2. It may be observed that, in agreement with previous results, when the rate of filtration is plotted against venous pressure the points are distributed about a straight line. This line passes through the line of zero filtration at a venous pressure of $14 \mathrm{~cm}$. water. The value obtained previously (1) was approximately $17 \mathrm{~cm}$. water. Above $14 \mathrm{~cm}$. water the rate of filtration is directly proportional to the venous pressure within the range tested. The unit rate of filtration, i.e. the change in filtration rate corresponding to a change of $1 \mathrm{~cm}$. water in venous pressure, amounts to $0.0028 \mathrm{cc}$. per minute per $100 \mathrm{cc}$. The value previously reported (1) for a congestion period of 30 minutes was $0.0023 \mathrm{cc}$. per minute per $100 \mathrm{cc}$.

Similar results were obtained in a series of experiments in which the period of venous congestion was diminished to 10 minutes. In Figure 3 are shown the filtration rates observed at a temperature of 34 to $35^{\circ} \mathrm{C}$. In this series after the usual control period in which two successive readings of "reduced arm volume" agreed to within $0.9 \mathrm{cc}$. or less, venous pressure was elevated to between 5 and $60 \mathrm{~cm}$. water. The congestion was continued for only 10 minutes and then released, to be followed immediately by another determination of "reduced arm volume." Under these circumstances the spread of the filtration rates observed at any given venous pressure was considerably greater. This was to be 
expected because of the greater error involved in measuring the smaller total amounts of fluid. The general relationship between venous pressure and rate of filtration is, however, the same in that the points are dis-

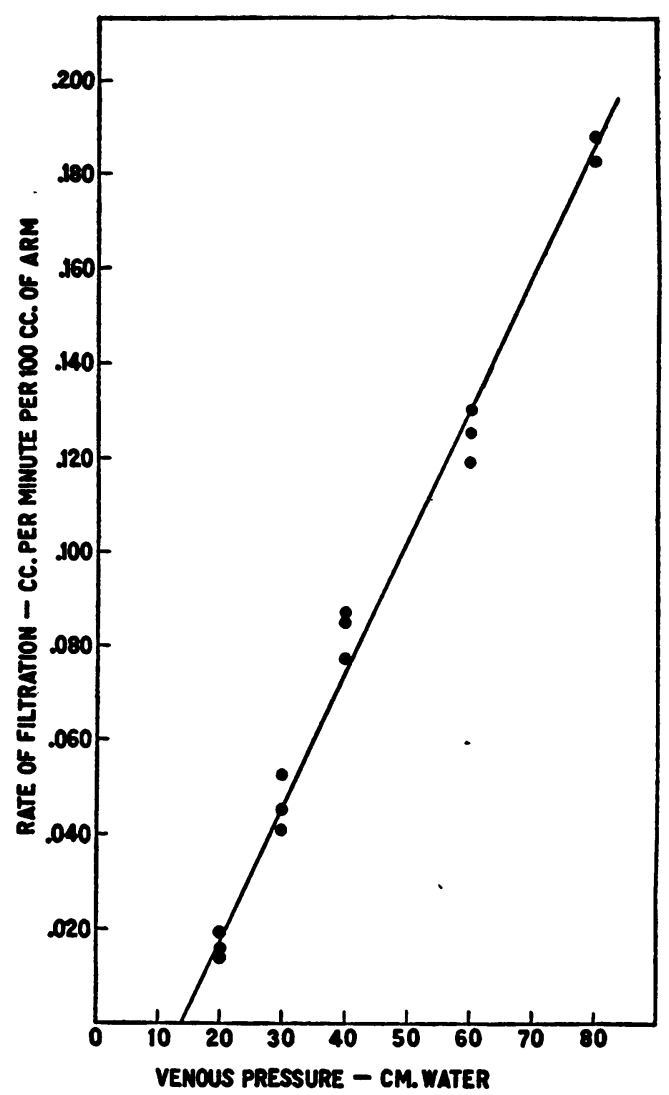

Fig. 2. Showing Rates of Filtration Produced during 30 Minutes by Venous Pressures between 20 and $80 \mathrm{~cm}$. Water

Plethysmograph temperature was 34 to $35^{\circ} \mathrm{C}$.

tributed about a straight line. This line intersects the line of zero filtration at $10 \mathrm{~cm}$. water. Above $10 \mathrm{~cm}$. water the rate of filtration is directly proportional to venous pressure. The rates of filtration obtained during 10- and 30-minute periods differ in two respects. In the first place the unit change in rate of filtration with the ten minute periods is somewhat greater than that observed with the thirty minute periods of congestion, amounting with the shorter period to $0.0033 \mathrm{cc}$. per minute per $100 \mathrm{cc}$. of arm for a change of $1 \mathrm{~cm}$. water in venous pressure. In the second place, at any given venous pressure the average rate of filtration in cc. per minute per $100 \mathrm{cc}$. of arm during 10 minutes is greater than that observed during thirty minutes. 


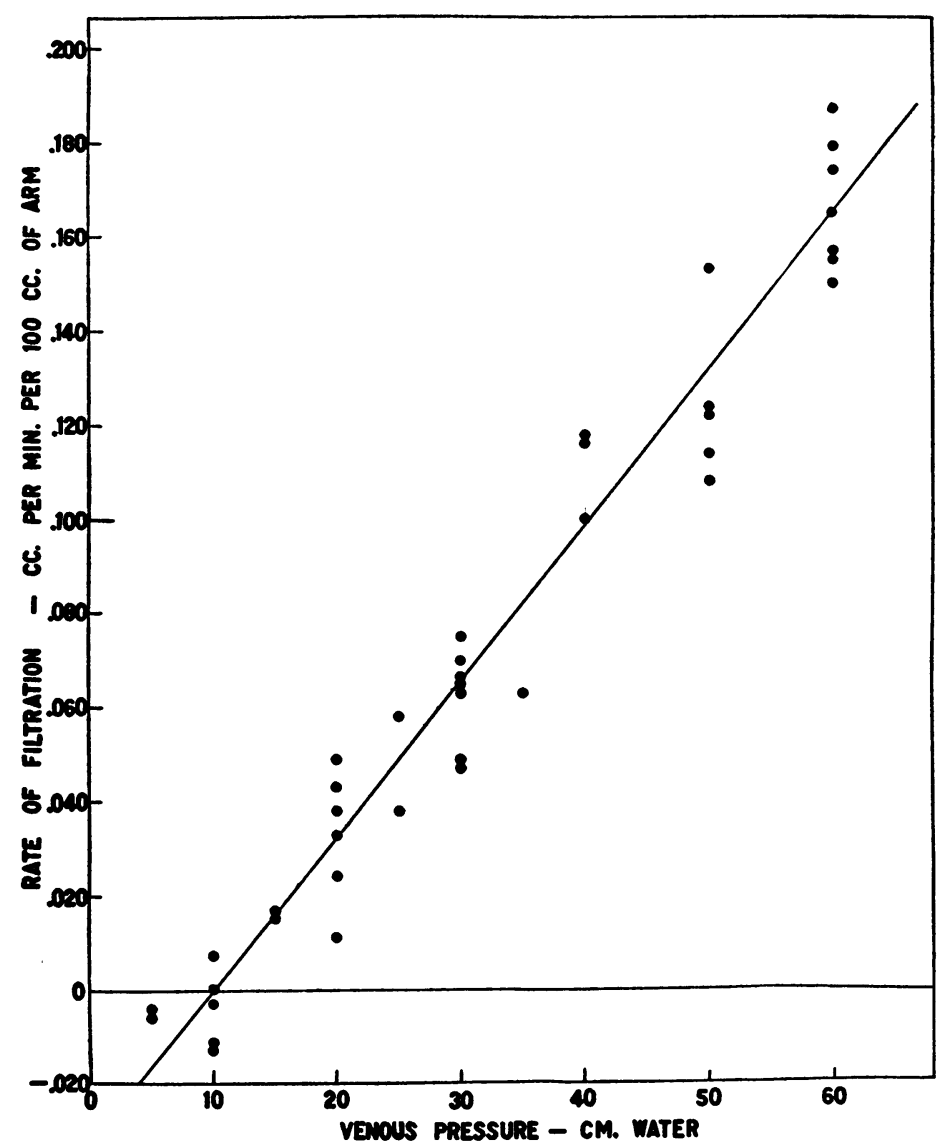

Fig. 3. Showing Rates of Filtration Produced during 10 Minutes by Venous Pressures between 5 and $60 \mathrm{~cm}$. Water

Plethysmograph temperature was 34 to $35^{\circ} \mathrm{C}$.

(B). The relation between local temperature and the rate of filtration

Drury and Jones (2) have already shown that at high venous pressures temperature conspicuously modifies the rate of filtration in the lower extremities. It seemed essential to determine whether a similar effect was to be observed at lower venous pressures more nearly within the physiological range. Figure 4 shows the change in "reduced arm volume" observed after ten minutes of congestion at $60 \mathrm{~cm}$. water with plethysmograph temperatures at 14 to 15,24 to 25,34 to 35 , and 44 to $45^{\circ} \mathrm{C}$. Each symbol (dot, circle, etc.) represents a determination of "reduced arm volume," requiring two minutes' stoppage of circulation. During the control period it may be observed that " reduced arm volume" diminished slightly. A venous pressure of $10 \mathrm{~cm}$. water failed, except at the lowest temperature, to produce any significant filtration. At 14 to 
$15^{\circ} \mathrm{C}$. a venous pressure of $60 \mathrm{~cm}$. water filtered during 10 minutes approximately $0.9 \mathrm{cc}$. of fluid per $100 \mathrm{cc}$. of tissue, or $6.3 \mathrm{cc}$. in a segment of forearm with a volume of $700 \mathrm{cc}$. At 24 to $25^{\circ} \mathrm{C}$., 34 to $35^{\circ} \mathrm{C}$. and 44 to $45^{\circ} \mathrm{C}$. the amount of filtered fluid became greater with each step in

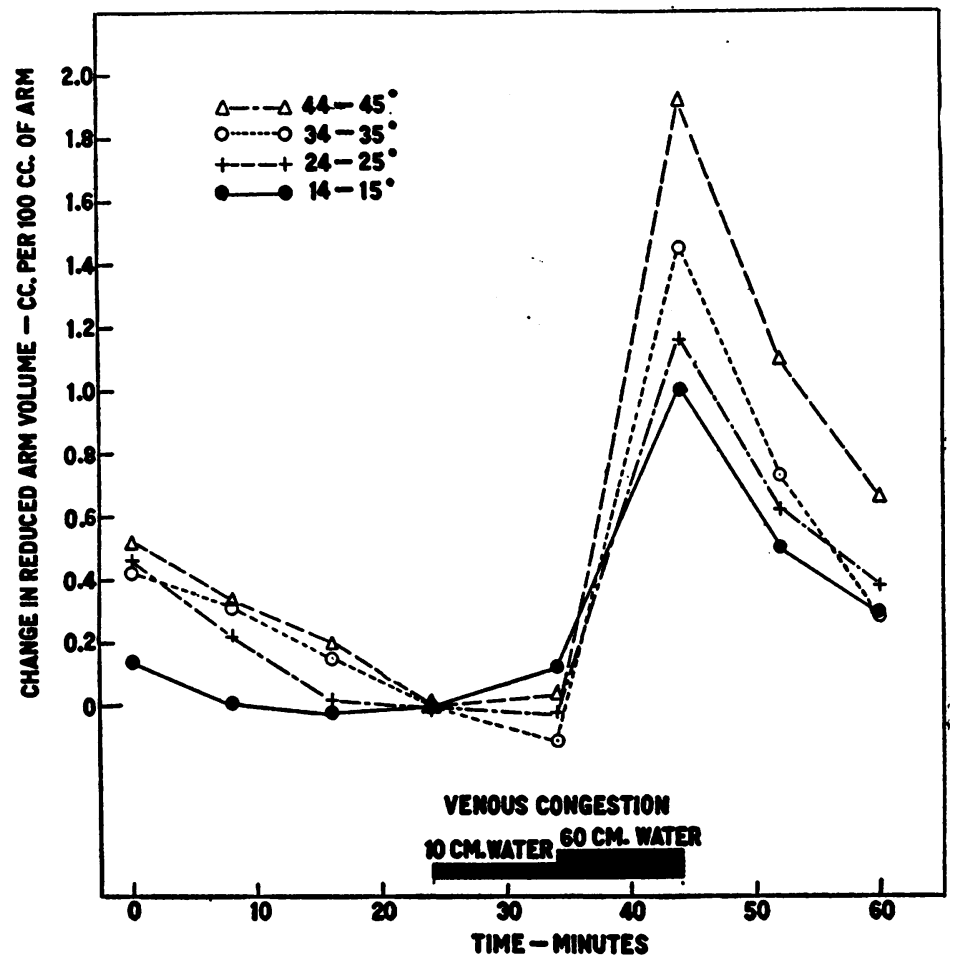

Fig. 4. Showing Change in "Reduced Arm Volume" Produced by Elevating Venous Pressure to $10 \mathrm{~cm}$. Water for Ten Minutes, and to $60 \mathrm{~cm}$. Water for Ten Minutes, at Temperatures of 14 to 15, 24 to 25, 34 To 35 , AND 44 To $45^{\circ} \mathrm{C}$.

Each symbol (circle, dot, etc.) represents a determination of "reduced arm volume" requiring two minutes' complete stoppage of blood flow.

temperature. The rate of filtration at 44 to $45^{\circ} \mathrm{C}$. was approximately twice that observed at 14 to $15^{\circ} \mathrm{C}$.

Table 1 shows the results of a larger series of observations made at these four temperatures, using venous pressures from 10 to $60 \mathrm{~cm}$. water. With a venous pressure of $10 \mathrm{~cm}$. water slight filtration was observed with a temperature of 14 to $15^{\circ} \mathrm{C}$. but no filtration could be detected at the higher temperatures. All the figures, however, are within the range of error of the method. With a venous pressure of 20 $\mathrm{cm}$. water filtration was observed at all temperatures but the average rates did not differ significantly, the average figures varying from $.031 \mathrm{cc}$. 


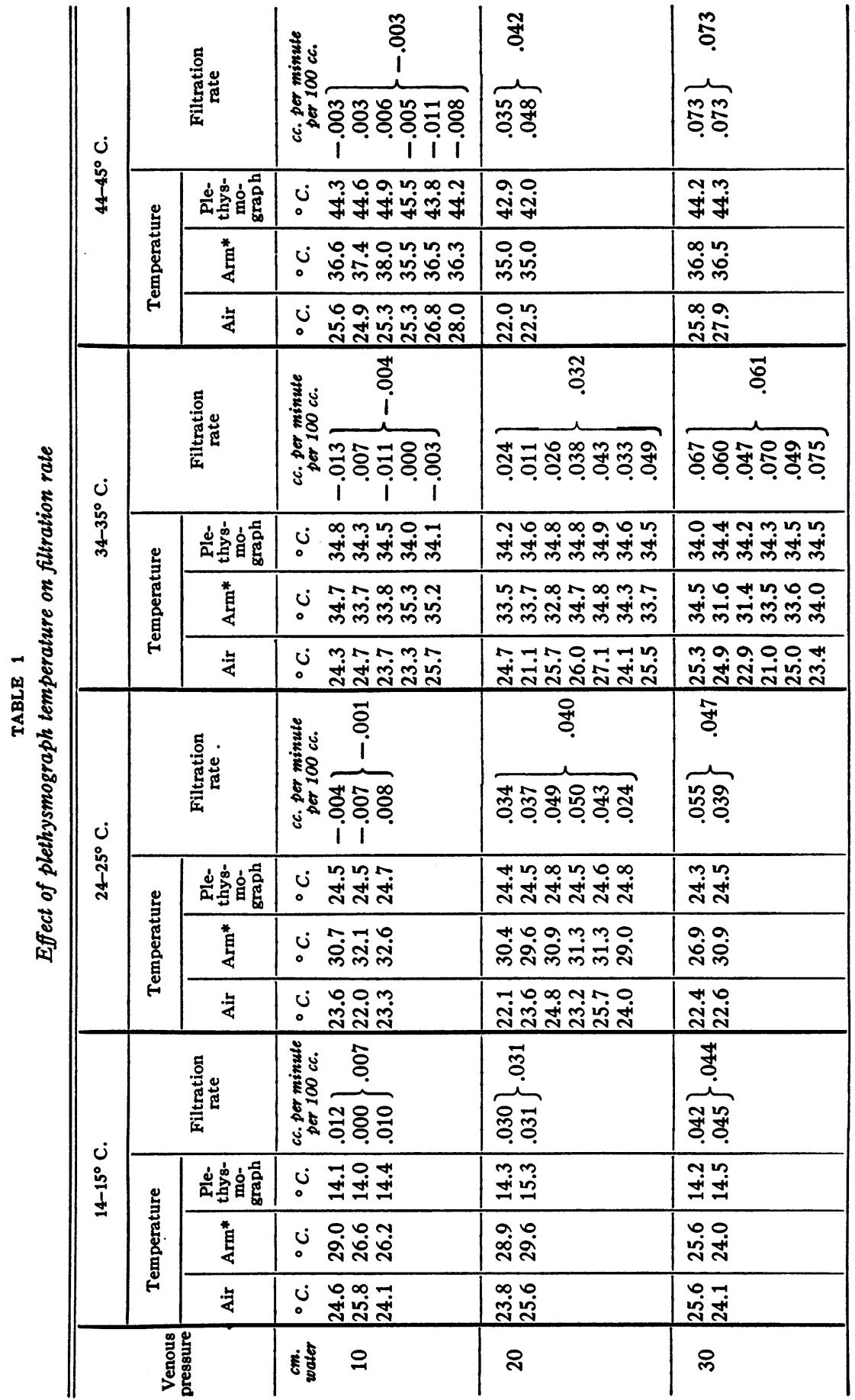


EUGENE M. LANDIS AND JOHN H. GIBBON, JR.

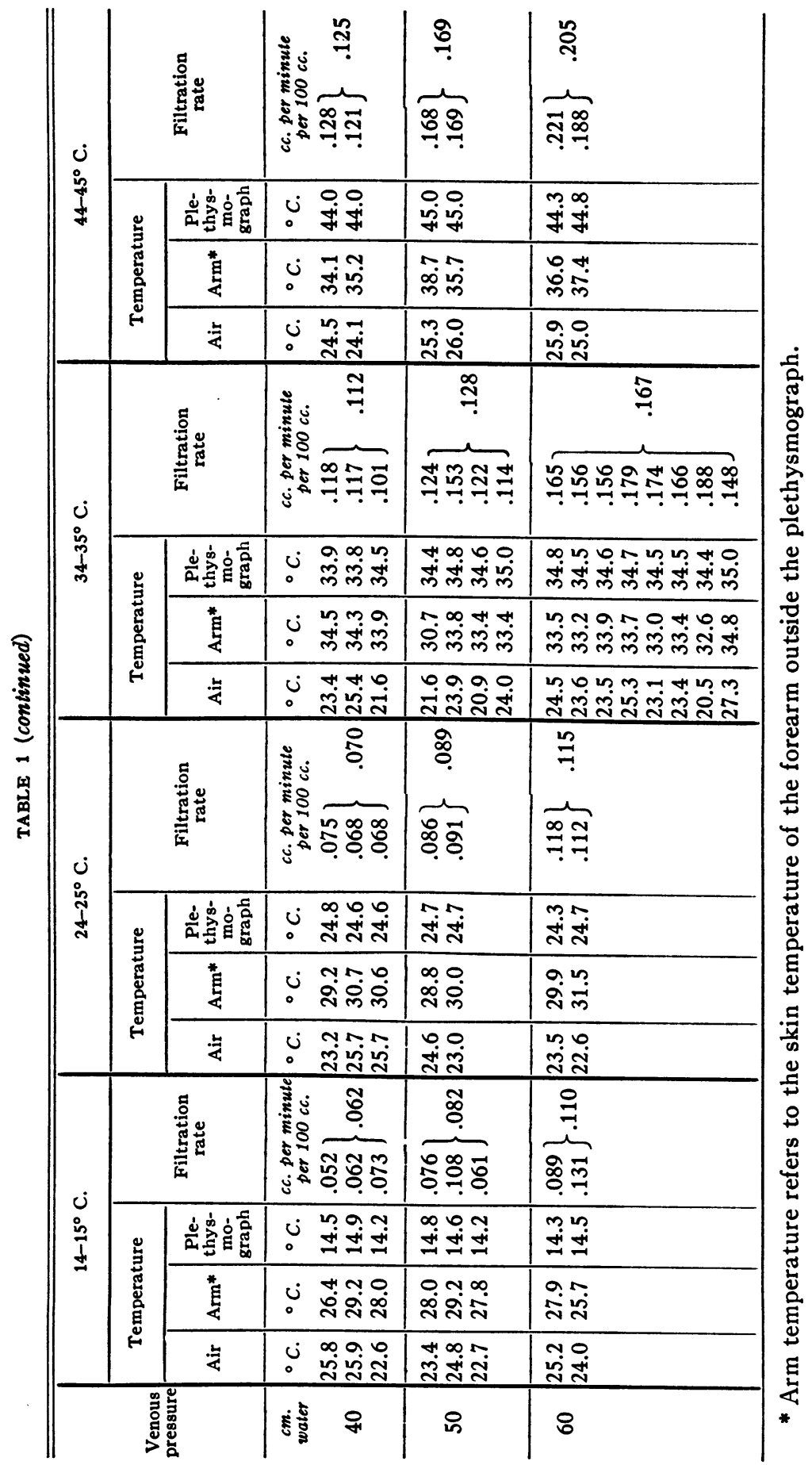


per minute per $100 \mathrm{cc}$. at 14 to $15^{\circ} \mathrm{C}$. to $.042 \mathrm{cc}$. per minute per $100 \mathrm{cc}$. at 44 to $45^{\circ} \mathrm{C}$. With venous pressures of $30,40,50$ and $60 \mathrm{~cm}$. water, however, the average filtration rates became uniformly greater with each step in temperature. Thus, a venous pressure of $30 \mathrm{~cm}$. water produced filtration at the rate of $.044 \mathrm{cc}$. per minute per $100 \mathrm{cc}$. at 14 to $15^{\circ} \mathrm{C}$. and $.073 \mathrm{cc}$. per minute per $100 \mathrm{cc}$. at 44 to $45^{\circ} \mathrm{C}$. Similar changes occurred with venous pressures of 40 and $50 \mathrm{~cm}$. The greatest change with temperature was observed with a venous pressure of $60 \mathrm{~cm}$. water; at 14 to $15^{\circ} \mathrm{C}$. the filtration rate was $.110 \mathrm{cc}$. per minute per $100 \mathrm{cc}$. rising to $.205 \mathrm{cc}$. per minute per $100 \mathrm{cc}$. at 44 to $45^{\circ} \mathrm{C}$.

From these results it appears that a rise in arm temperature conspicuously increases the effectiveness of a given venous pressure in filtering fluid into the tissue spaces. It may be concluded that the temperature effect observed by Drury and Jones (2) at high venous pressures is of importance also at venous pressures as low as $30 \mathrm{~cm}$. water.

\section{(C). The effects of tissue pressure on the filtration of fluid}

Lewis and Grant (3) observed that when relatively high pressures were thrown on to the veins the volume curve registered by the ordinary plethysmograph rose rapidly at first and then continued mounting gradually. They stated that the first part of the volume curve showed an increase in arm volume due to engorgement of the veins with blood held back by the cuff, while the second upward movement, slower and more prolonged, was due in part to distention of the blood vessels and in part to tissue edema.

The correctness of this view is shown by the relation between "reduced arm volume" and total arm volume during prolonged periods of venous congestion such as are indicated in Figure 5. In these two observations after the preliminary control period (not shown in Figure 5), in which several readings of "reduced arm volume" and total arm volume had been made, the armlet was inflated and the change in total arm volume recorded. Immediately before each subsequent determination of "reduced arm volume" pressure in the armlet was released, and immediately after each determination was completed (two minutes) the armlet was again rapidly inflated. Each point on the curves of Figure 5 therefore represents a two-minute period during which circulation was stopped. The readings of total arm volume recorded immediately before each determination of "reduced arm volume" have been charted for comparison with the readings of "reduced arm volume." The circles connected by dotted lines represent changes in total arm volume when the veins were congested by a pressure of $30 \mathrm{~cm}$. water. The circles connected with solid lines represent changes in "reduced arm volume" over the same period. 
It may be observed that a venous pressure of $30 \mathrm{~cm}$. water increased total arm volume by $25 \mathrm{cc}$. during the first five minutes. This change in volume was due in part to distention of the veins and in part to accumulation of fluid in the tissue spaces. During the same period of

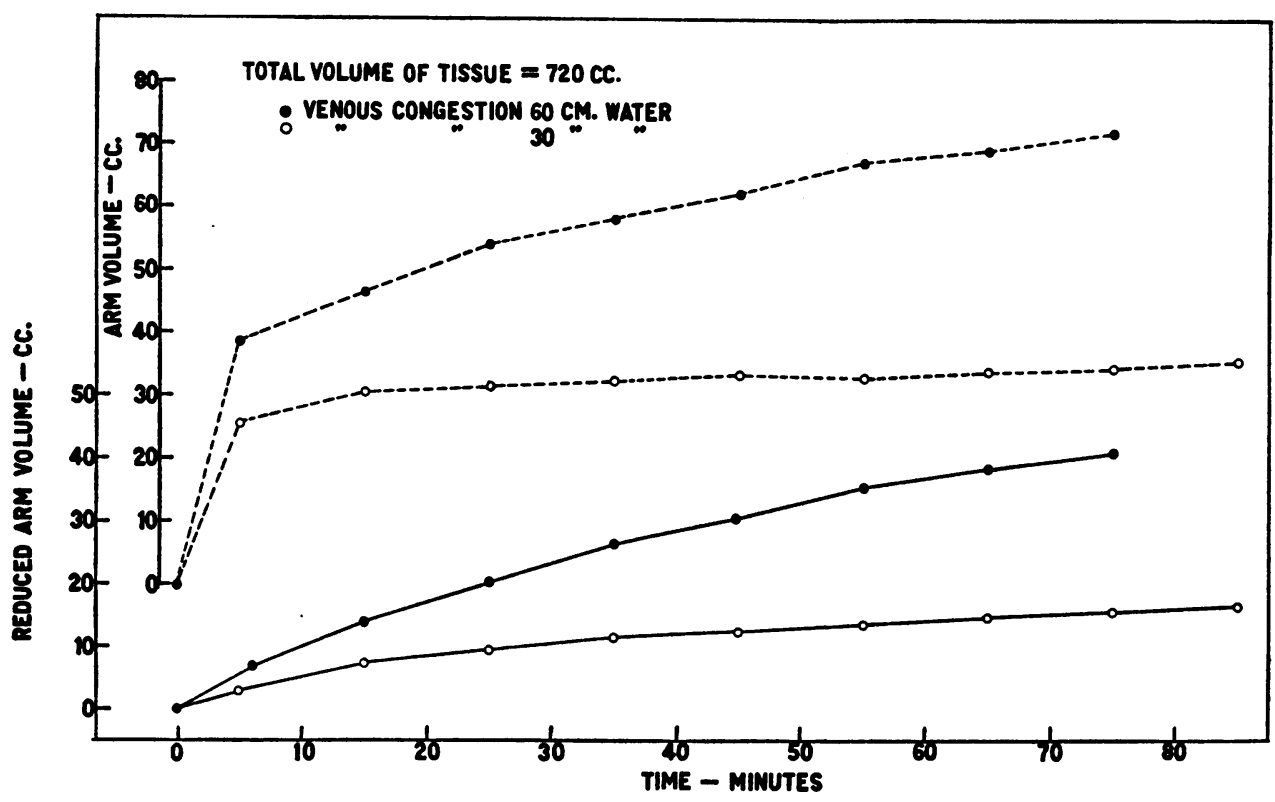

Fig. 5. Showing Change in Arm Volume and in "Reduced Arm Volume" Produced by Venous Pressures of 30 cm. Water and 60 cm. Water, with a Plethysmograph Temperature of 34 to $35^{\circ} \mathrm{C}$.

congestion "reduced arm volume" had increased by only $3 \mathrm{cc}$., the remaining $22 \mathrm{cc}$. representing therefore venous engorgement. In the following ten minute period of congestion arm volume became $5 \mathrm{cc}$. greater, "reduced arm volume" having increased simultaneously by 4.5 cc. Thereafter the curves of total arm volume and "reduced arm volume" were almost parallel indicating that after the first 15 minutes of congestion changes in total arm volume were due almost wholly to accumulation of fluid in the tissue spaces.

The difference between the forms of the curves showing arm volume and "reduced arm volume" provide additional evidence that the latter measurements were independent of the amount of blood imprisoned in the veins at the time each determination was begun.

Similar results were observed when venous pressure was elevated to $60 \mathrm{~cm}$. water. Total arm volume during the first 5 minutes increased by 38 cc. whereas "reduced arm volume" during the first six minutes increased by only $7 \mathrm{cc}$. Again after the first fifteen minutes of congestion 
"reduced arm volume" rose at approximately the same rate as did total arm volume.

In both curves of "reduced arm volume" the rate of change is most rapid during the first few minutes becoming gradually slower as the period of congestion lengthens. Thus, during the first 6 minutes a venous pressure of $60 \mathrm{~cm}$. water filtered fluid at a rate of $1.0 \mathrm{cc}$. per minute, whereas during the last ten minutes of a 75 minute period the same venous pressure filtered fluid at a rate of only $.25 \mathrm{cc}$. per minute.

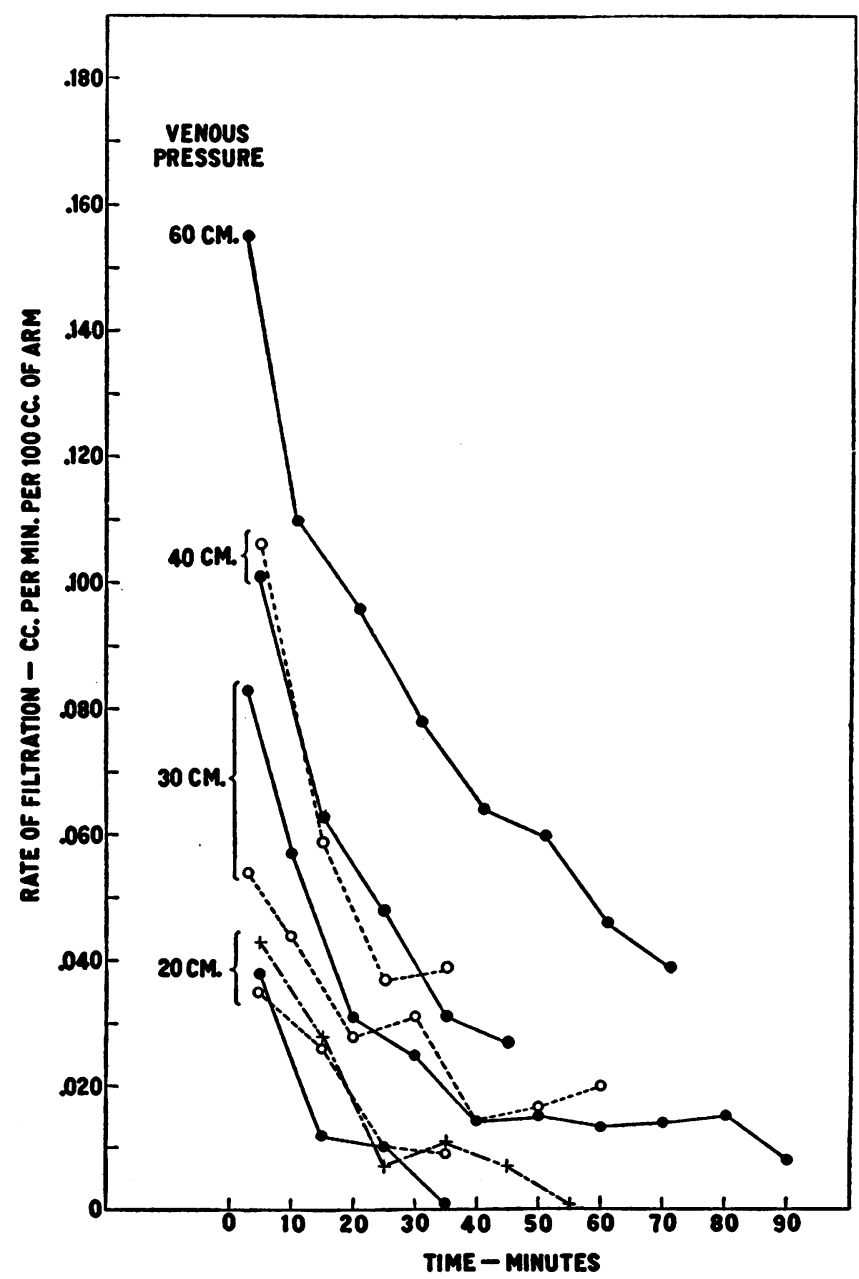

Fig. 6. Showing the Chañge in the Rate of Filtration When Venous Pressure was Elevated for Long Periods of Time

The gradual decrease in filtration rate when venous pressure was elevated over a long period of time is shown in Figure 6. In this series of 
observations venous pressure was elevated to $20,30,40$ or $60 \mathrm{~cm}$. water for periods totalling between 35 to 90 minutes, while "reduced arm volumes" were determined repeatedly usually at intervals of 10 minutes. The rate of filtration produced by any given venous pressure decreased conspicuously as the period of congestion lengthened. Thus a venous pressure of $60 \mathrm{~cm}$. water filtered fluid into the tissue spaces at the rate of $.156 \mathrm{cc}$. per minute per $100 \mathrm{cc}$. of arm during the first 6 minutes. The rate was reduced to .110 between the 7 th and 15 th minutes, and to .040 between the 65th and 75th minutes.

Similar results were obtained with a venous pressure of $40 \mathrm{~cm}$. water. Filtration rates originally slightly above $.100 \mathrm{cc}$. per minute per $100 \mathrm{cc}$. of arm were reduced after 35 or 40 minutes to less than $.040 \mathrm{cc}$. per minute per $100 \mathrm{cc}$. of arm. A venous pressure of $30 \mathrm{~cm}$. water filtered fluid at rates of .054 and $.085 \mathrm{cc}$. per minute per $100 \mathrm{cc}$. of arm during the first 5 minutes and at rates of .020 and $.013 \mathrm{cc}$. per minute per $100 \mathrm{cc}$. of arm at the end of 60 minutes. A venous pressure of $20 \mathrm{~cm}$. water filtered fluid at a rate of about $.040 \mathrm{cc}$. per minute per $100 \mathrm{cc}$. of arm during the first 10 minutes of congestion. In two experiments no filtration could be detected after $\mathbf{3 5}$ and $\mathbf{5 5}$ minutes of congestion respectively. From this it appears that a venous pressure of $20 \mathrm{~cm}$. water may after a time completely lose its power to produce filtration. A venous pressure of $\mathbf{3 0}$ $\mathrm{cm}$. water produced filtration even after a period of 90 minutes.

From the preceding results it is obvious that the effectiveness of any given venous pressure in producing filtration depended, among other things, upon the length of time during which the venous pressure had been acting. The longer the period of congestion, the greater was the volume of fluid in the tissue spaces and the slower the rate of filtration. If this change in filtration rate is due to the accumulation of fluid the filtration rate observed should depend upon the amount of fluid in the tissue spaces and not upon the venous pressure which caused it to accumulate there.

This was tested by measuring filtration during alternating periods of congestion with pressures of 20 (or 40 ) $\mathrm{cm}$. water and $60 \mathrm{~cm}$. water, as shown in Figure 7. After a series of control measurements of "reduced arm volume" venous pressure was elevated for a period of ten minutes to $60 \mathrm{~cm}$. water. The second determination of "reduced arm volume" was followed in one experiment by a ten-minute period at $40 \mathrm{~cm}$. and in another by a similar period at $20 \mathrm{~cm}$. This alternation of high and low venous pressures was continued until fluid was no longer filtered at the lower pressures.

When venous pressure was raised to $60 \mathrm{~cm}$. water during a series of short periods the "reduced arm volume" increased more and more slowly during each succeeding ten minute period (Figure 7, dots and solid lines). When venous pressure was raised alternately to $60 \mathrm{~cm}$. and 40 
$\mathrm{cm}$. water the latter pressure produced slight filtration on the first occasion, negligible filtration on the second, and on the third and fourth occasions fluid was slowly removed (Figure 7 , circles and dotted lines). Hence, elevating venous pressure to $60 \mathrm{~cm}$. water for a sufficiently long period of time completely prevented subsequent filtration at $40 \mathrm{~cm}$. water. Apparently an accumulation of $4 \mathrm{cc}$. of fluid per $100 \mathrm{cc}$. of tissue was sufficient to abolish the further filtration of fluid by a venous pressure of $40 \mathrm{~cm}$. water.

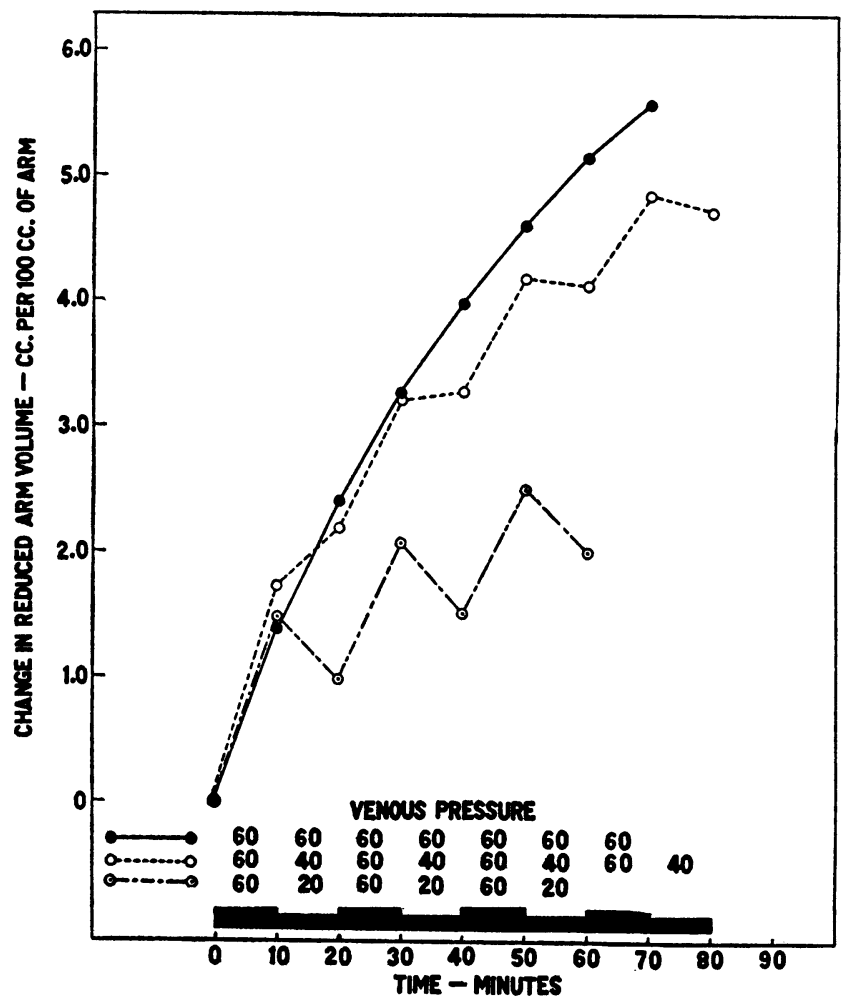

Fig. 7. Showing Change in "Reduced Arm Volume" (a) During A Series of Periods with a Venous Pressure of $60 \mathrm{~cm}$. Water, (b) During a Series of Periods with Venous Pressures of 60 and 40 cm. Water Alternately, and (c) During a Series of Periods with Venous Pressures of 60 and $20 \mathrm{~cm}$. Water Alternately.

In previous observations a venous pressure of $20 \mathrm{~cm}$. water always produced slight but definite filtration into a forearm containing only the normal amount of tissue fluid. A single ten-minute period of venous congestion at $60 \mathrm{~cm}$. water pressure was sufficient, however, to abolish the filtration usually produced by $20 \mathrm{~cm}$. water. The accumulation of $1.5 \mathrm{cc}$. of fluid per $100 \mathrm{cc}$. of arm resulted in the rapid removal of fluid even with a venous pressure of $20 \mathrm{~cm}$. water. 
The decrease in filtration rate observed at various venous pressures from 20 to $60 \mathrm{~cm}$. water has been charted in Figure 8 against the volume of tissue fluid in the arm at the beginning of the congestion period. Each point represents the filtration rate observed during a period of ten minutes. The amount of fluid in the tissues of the forearm at the beginning of this period was computed from known increase in "reduced

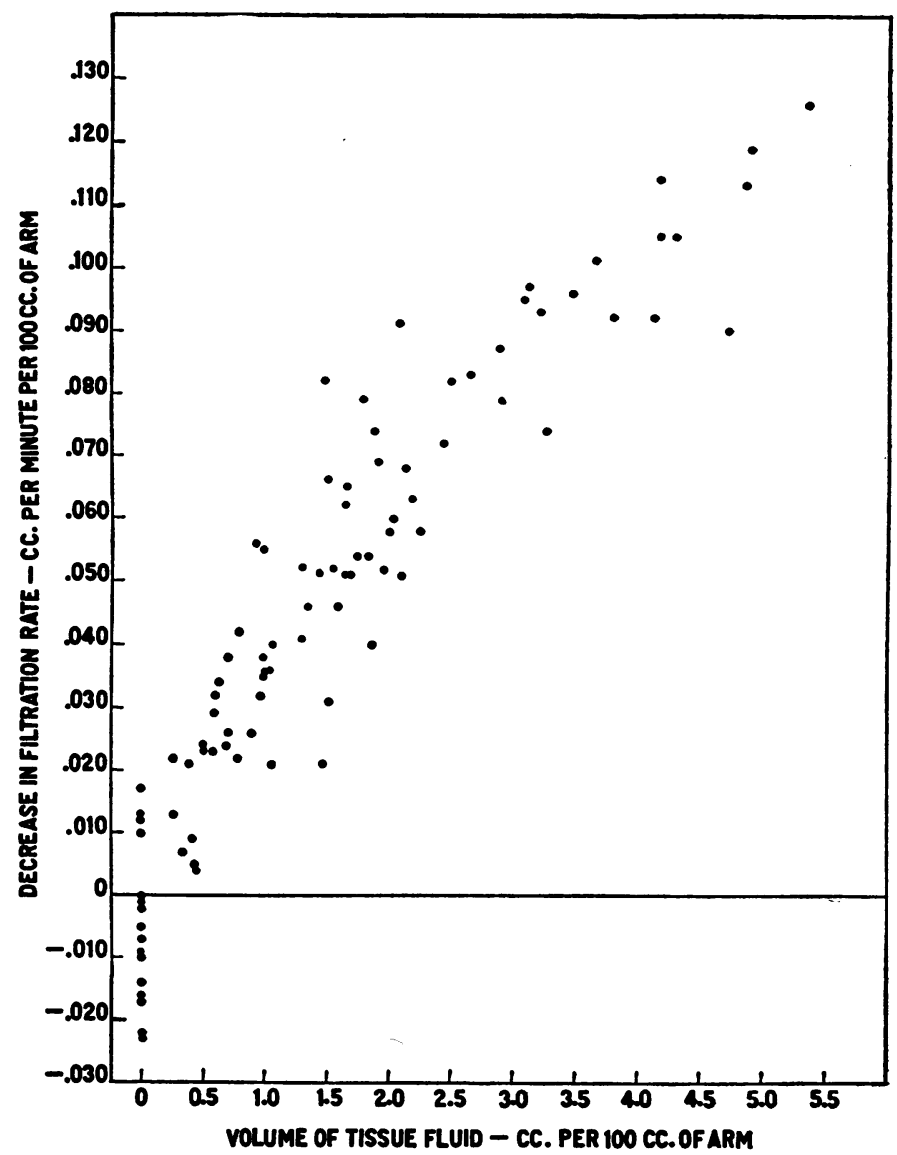

Fig. 8. Showing the Effect of Accumulations of Tissue Fluid on For full description see text.

Filtration Rate

arm volume" produced by previous congestion. The filtration rate observed at venous pressures of 20,40 or $60 \mathrm{~cm}$. water with a known volume of fluid in the tissue spaces was subtracted from the average filtration rate observed (Figure 3) at the same venous pressure when no fluid had been previously filtered into the arm. The difference between these two filtration rates was charted against the volume of tissue fluid present at the beginning of the congestion period. 
It may be observed from Figure 8 that the greater the volume of tissue fluid the more conspicuous was the decrease in filtration rate. The points arrange themselves roughly about a curve which approaches a straight line in its left hand portion. When the excess tissue fluid amounted to $5.0 \mathrm{cc}$. per $100 \mathrm{cc}$. of forearm the filtration rates were on the average $.110 \mathrm{cc}$. per minute per $100 \mathrm{cc}$. of arm less than the filtration rates observed at the same venous pressures in a forearm free of previously filtered fluid.

From previous results (Figure 3 ) it was computed that when filtration was measured in 10-minute periods a change in venous pressure of $1 \mathrm{~cm}$. water modified the filtration rate by $.0033 \mathrm{cc}$. per minute per $100 \mathrm{cc}$. of arm. A change in filtration rate of .110 corresponds to a change in venous pressure of approximately $35 \mathrm{~cm}$. water. Thus, in the presence of an accumulation of tissue fluid amounting to $5.0 \mathrm{cc}$. per $100 \mathrm{cc}$. of arm a venous pressure of $60 \mathrm{~cm}$. water filters fluid at a rate comparable to that produced by a venous pressure of $25 \mathrm{~cm}$. water in a forearm containing only the normal amount of tissue fluid. It would be expected that if $5.0 \mathrm{cc}$. of fluid per $100 \mathrm{cc}$. of arm were already present, a venous pressure of 20 or $40 \mathrm{~cm}$. water would be unable to produce further filtration. This was actually the case, as shown in Figure 7.

It might possibly be argued that these findings were artefacts produced by the method of measuring "reduced arm volume." When venous pressure is elevated for a prolonged period the amount of tissue fluid increases. If the application of a pressure of $200 \mathrm{~mm}$. $\mathrm{Hg}$ to the forearm squeezed large amounts of fluid from the tissues inside the plethysmograph into the tissues just outside, the amount of fluid thus lost would probably become greater as the amount of tissue fluid increased. Under these conditions, the decrease in filtration rate might be regarded as due to purely mechanical errors introduced by the method. That this is definitely not the case is shown in Table 2 . In this series of observations after the usual control readings had been made venous pressures of 20,30, 40 or $60 \mathrm{~cm}$. water were used $(a)$ in a series of short periods, one following immediately after the other, and $(b)$ in one long period having a duration equal to the sum of the short periods. Now, during a total filtration period of 30 minutes when determinations were made after each of three consecutive ten-minute periods of congestion, the arm was compressed three times while with a single long filtration period of like duration the arm was compressed only once. If there were any significant decrease of "reduced arm volume" directly due to the external application of pressure it would be expected that the observation including three determinations would show a much smaller change in volume than the observation requiring but one determination. 
TABLE 2

A comparison of the amount of fuid filtered at various venous pressures during several successive short periods and during a single long period

\begin{tabular}{|c|c|c|c|c|c|c|c|c|c|c|c|}
\hline \multirow{2}{*}{$\begin{array}{c}\text { Venous } \\
\text { pressure }\end{array}$} & & \multicolumn{2}{|c|}{$\begin{array}{l}\text { Successive } \\
\text { short periods }\end{array}$} & \multicolumn{2}{|c|}{$\begin{array}{c}\text { Single } \\
\text { long period }\end{array}$} & \multirow{2}{*}{$\begin{array}{c}\text { Venous } \\
\text { pressure }\end{array}$} & & \multicolumn{2}{|c|}{$\begin{array}{l}\text { Successive } \\
\text { short periods }\end{array}$} & \multicolumn{2}{|c|}{$\begin{array}{c}\text { Single } \\
\text { long period }\end{array}$} \\
\hline & & $\underset{\text { tion }}{\text { Dura- }}$ & $\begin{array}{l}\text { Fluid } \\
\text { filtered }\end{array}$ & $\underset{\text { tion }}{\text { Dura- }}$ & $\begin{array}{l}\text { Fluid } \\
\text { filtered }\end{array}$ & & & Dura- & $\begin{array}{l}\text { Fluid } \\
\text { filtered }\end{array}$ & Dura- & Fluid \\
\hline \multirow[t]{5}{*}{$\underset{\text { water }}{\text { cm. }}$} & & minutes & $\begin{array}{l}\text { cc. per } \\
100 \text { cc. } \\
\text { of arm }\end{array}$ & \multirow[t]{5}{*}{ minutes } & \multirow{5}{*}{$\begin{array}{c}c c . \text { per } \\
100 \text { cc. } \\
\text { of arm } \\
.48\end{array}$} & \multirow[t]{6}{*}{$\underset{\text { water }}{\mathrm{cm} .}$} & & minutes & $\begin{array}{l}c c . \text { per } \\
100 \mathrm{cc} \text {. } \\
\text { of arm }\end{array}$ & \multirow[t]{6}{*}{ minutes } & \multirow{6}{*}{$\mid \begin{array}{l}c c . \text { per } \\
100 \text { cc. } \\
\text { of arm } \\
1.58\end{array}$} \\
\hline & & $10^{*}$ & .33 & & & & & 5 & .42 & & \\
\hline & & $10^{*}$ & .26 & & & & & 10 & $\begin{array}{r}.57 \\
31\end{array}$ & & \\
\hline & & $10^{*}$ & .10 & & & & & 10 & .31 & & \\
\hline & Total & 30 & .69 & & & & & 10 & .25 & & \\
\hline \multirow{3}{*}{20} & & $10^{*}$ & .38 & \multirow{3}{*}{30} & \multirow{3}{*}{.58} & & Total & 35 & 1.55 & & \\
\hline & & $\begin{array}{l}10^{*} \\
10^{*}\end{array}$ & $\begin{array}{l}.12 \\
.10\end{array}$ & & & \multirow[t]{3}{*}{40} & & $\begin{array}{l}10 \\
10\end{array}$ & $\begin{array}{r}1.02 \\
.63\end{array}$ & \multirow[t]{3}{*}{30} & \multirow[t]{3}{*}{2.62} \\
\hline & Total & 30 & .60 & & & & & 10 & .48 & & \\
\hline \multirow{4}{*}{20} & & $10^{*}$ & .43 & \multirow{4}{*}{30} & \multirow{4}{*}{.43} & & Total & 30 & 2.13 & & \\
\hline & & $10^{*}$ & .28 & & & \multirow{4}{*}{40} & & 10 & 1.06 & & \\
\hline & & $10^{*}$ & .07 & & & & & 10 & .59 & 30 & 2.31 \\
\hline & Total & 30 & .78 & & & & & 10 & .37 & & \\
\hline \multirow{5}{*}{30} & & $5^{*}$ & .45 & \multirow{5}{*}{35} & \multirow{5}{*}{1.87} & & Total & 30 & 2.02 & 30 & 2.54 \\
\hline & & $10^{*}$ & .62 & & & \multirow{5}{*}{60} & & 6 & .93 & \multirow{5}{*}{35} & \multirow{5}{*}{4.15} \\
\hline & & $10^{*}$ & .45 & & & & & 9 & .99 & & \\
\hline & & $10^{*}$ & .34 & & & & & 10 & .96 & & \\
\hline & Total & 35 & 1.86 & & & & & 10 & .78 & & \\
\hline \multirow{4}{*}{30} & & 5 & .27 & \multirow{4}{*}{35} & \multirow{4}{*}{1.43} & & Total & 35 & 3.66 & & \\
\hline & & 10 & .44 & & & \multirow{3}{*}{60} & & 10 & 1.79 & & \\
\hline & & $\begin{array}{l}10 \\
10\end{array}$ & $\begin{array}{l}.28 \\
31\end{array}$ & & & & & $\begin{array}{l}10 \\
10\end{array}$ & $\begin{array}{l}.86 \\
82\end{array}$ & 30 & 3.75 \\
\hline & Total & 35 & 1.30 & & & & Total & 30 & 3.47 & 30 & 3.90 \\
\hline
\end{tabular}

*Venous congestion continued during readings of "reduced arm volume."

Examination of the figures in Table 2 will show that this was not the case. Thus in three experiments with a venous pressure of $20 \mathrm{~cm}$. water the amount of fluid filtered in the single long period was not greater than the amount of fluid filtered in three short periods of like total duration. The same was true with a venous pressure of $30 \mathrm{~cm}$. water. For example, in 35 minutes a venous pressure of $30 \mathrm{~cm}$. water applied continuously filtered $1.87,1.43$ and $1.58 \mathrm{cc}$. of fluid per $100 \mathrm{cc}$. of arm. The same venous pressure, applied for one period of five minutes and three of ten minutes each, filtered total volumes of fluid amounting to $1.86,1.30$ and $1.55 \mathrm{cc}$. The difference between these two sets of figures is not significant. At venous pressures of 40 and $60 \mathrm{~cm}$. water the totals differed by not more than $0.52 \mathrm{cc}$. per $100 \mathrm{cc}$. of arm indicating that the amount lost with each single determination of "reduced arm volume" is, at most, $0.25 \mathrm{cc}$. per $100 \mathrm{cc}$. of arm for each two-minute period of $200 \mathrm{~mm}$. 
$\mathrm{Hg}$ pressure. This is much too small to explain the decreasing filtration in prolonged periods of congestion. This, we believe, is due to mounting tissue pressure in the intercellular spaces distended by the filtered fluid.

\section{(D). The rate at which tissue fuid is removed}

The volume of tissue fluid present in the forearm exerts a significant effect on the rate at which that fluid is removed. The method of determining the rate of removal of fluid consisted in repeating the observations of "reduced arm volume" at intervals of 10 minutes after the end of one or more periods of congestion. When venous pressure was not elevated the rate at which fluid was removed from the tissue spaces depended primarily upon the amount of fluid present. When a large amount of tissue fluid was present the "reduced arm volume" returned to normal very much more rapidly than when a small amount of tissue fluid was present.

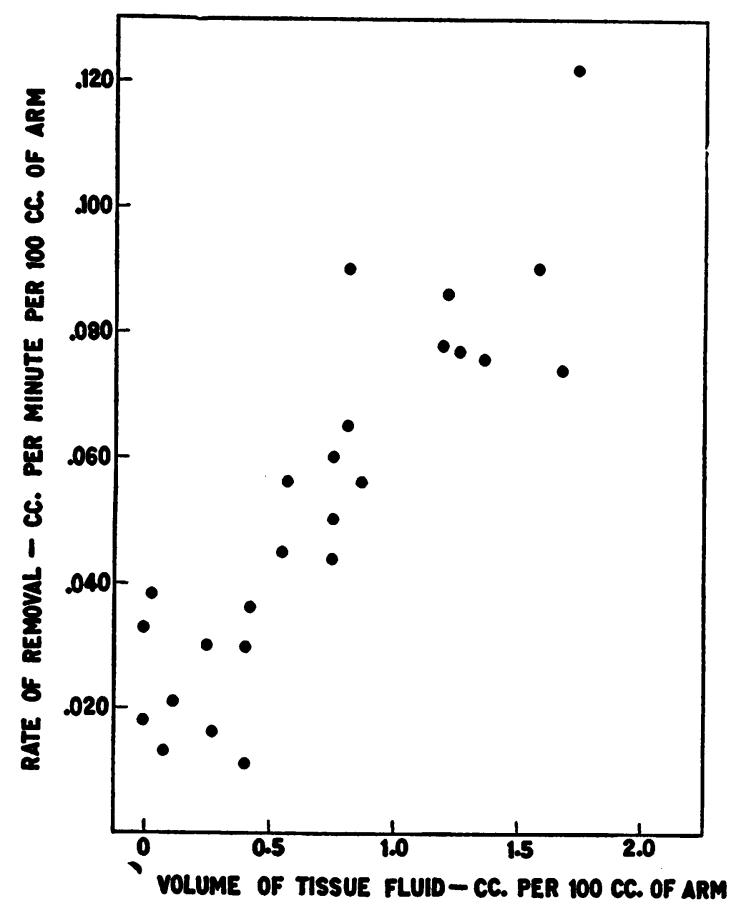

Fig. 9. Showing the Relation between the Volume of Tissue Fluid and the Rate of Removal of that Fluid Plethysmograph temperature was 34 to $35^{\circ} \mathrm{C}$.

The change in "reduced arm volume" during the removal of fluid is shown in Figure 4. In these observations at the end of the filtration period the armlet was deflated and two or more readings of "reduced arm volume" were made at intervals of ten minutes. The relation between 
the volume of tissue fluid and the rate of removal is shown by Figure 9 which includes only observations made at a temperature of 34 to $35^{\circ} \mathrm{C}$. The points are distributed roughly about a straight line. The scattering, however, is so great that it hardly seems justifiable to draw any conclusions concerning the slope and position of that line. It is clear, however, that the rate at which fluid leaves the forearm is related to the amount of tissue fluid which has accumulated during the preceding period or periods of filtration.

The effect of temperature on the removal of fluid is not striking except possibly at 14 to $15^{\circ} \mathrm{C}$. Inspection of Figure 10 will show that the points

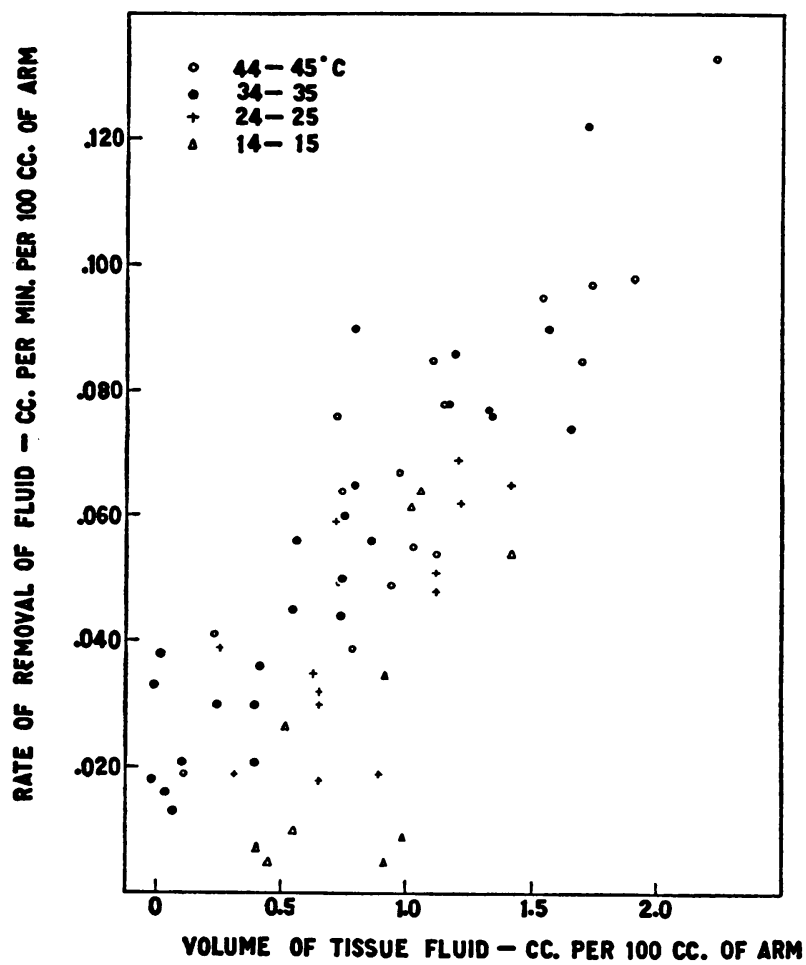

Fig. 10. Showing the Effect of Temperature on the Rate at Which Tissue Fluid was Removed When Varying Volumes of Tissue Fluid WERE PRESENT.

representing the removal of fluid at 44 to 45,34 to 35 , and 24 to $25^{\circ} \mathrm{C}$. are distributed over approximately similar areas. However, when the plethysmograph temperature was dropped to 14 to $15^{\circ} \mathrm{C}$. small amounts of tissue fluid sometimes failed to leave the tissues as rapidly as similar amounts when the forearm was at a higher temperature. On the other hand, when large amounts of fluid had accumulated the rate of removal was only slightly, if at all, slower at the lower temperature. 


\section{DISCUSSION}

There is evidence from several sources that temperature modifies the balance between tissue fluid and the fluids of the circulating blood. Bazett (4) has called attention to the common knowledge that the limbs swell during warm weather and shrink during cold weather. This change in volume may be due to some extent to the amount of blood in the tissues, though the rate of change is too slow to be explained satisfactorily on this basis. It is a matter of common observation also that rings, gloves, and shoes appear to be tighter in summer than in winter. Experimentally Okuneff (5) has shown that dyes pass more rapidly into areas of tissue which have been heated. Moreover, dyes are removed more rapidly by way of the lymphatic vessels from such heated areas. Drury and Jones (2) immersed the legs and feet in baths ranging in temperature from 14 to $42^{\circ} \mathrm{C}$. and found, with the ordinary plethysmograph, that the filtration produced by venous pressures of 40 to $80 \mathrm{~mm}$. Hg was very much greater at the higher temperatures.

Indirect measurements by Lewis and Haynal (6) and direct determinations by Landis (7) indicate that warming the skin elevates cutaneous capillary pressure conspicuously. Moreover, local heat, by dilating capillaries previously closed or only partially open, must increase the total filtering area quite considerably. Both factors, or either factor singly, would tend to increase the filtration rate at any given venous pressure. It is impossible to estimate the relative importance of these two possibilities from the data at present available.

Hamilton and Barbour (8) studied the effects of cold on the transport of fluid from the blood to the tissue spaces. When anesthetized dogs were kept lying on slabs of ice for 20 to $\mathbf{5 0}$ minutes immediately before they were killed, it was possible to demonstrate a larger content of water in the subcutaneous tissue and muscle of the cooled side. Barbour and Hamilton (9) postulated, therefore, that exposure to cold produces anhydremia because fluid is diverted to the cooled skin, subcutaneous tissues and muscles as a result of arteriolar constriction, capillary dilatation from anoxemia, and increased permeability. In the plethysmographic studies here described lowering the temperature of the forearm to $14.5^{\circ} \mathrm{C}$. did not cause the "reduced arm volume" to increase. As Bazett (4) points out, the generalizations made by Barbour and Hamilton seem unwarranted at present for no control observations were made to determine the effect of gravity. Moreover, an ice block might well be an excessive stimulus, giving results comparable with slight frost-bite rather than with those of ordinary cold. Lewis (10) has postulated that the reactive vasodilatation which comes on when the skin is cooled below $15^{\circ} \mathrm{C}$. is due to an axone reflex, stimulated by injury and the release of $\mathrm{H}$-substance in the cooled skin. 
In studies of active muscle and secreting glands Barcroft and Kato (11) recorded rates of lymph flow in cc. per gram of tissue per minute. These figures, obtained indirectly by comparing hemoglobin contents of arterial and venous blood, are considerably greater than the highest rates of filtration found in the forearm during simple congestion. The rapid flow of lymph from active tissues may be partly due to the extravascular accumulation of metabolites suggested by Asher and Barbèra (12).

The striking effect of temperature on the filtration rate at venous pressures of $\mathbf{3 0}$ or more $\mathrm{cm}$. water is of particular interest with regard to the appearance of edema, particularly of those types related to climatic changes. Frequently patients with mild edema complain that the swelling of the lower extremities is greater during warm weather than during cold. Castellani (13), in a recent review of minor tropical diseases, mentions two types of heat edema. The milder form is "extremely common all over the tropics, and Europeans on their way to the East frequently develop it as soon as the boat reaches the southern portion of the Red Sea and Aden." The feet and legs swell slightly and pitting may occasionally occur, without any evidence of renal or cardiac abnormality. A more severe form, "heat oedema gravis," was observed by Castellani in Europe and America during severe heat waves. The edema comes on suddenly, lasts as long as the high temperature persists and then disappears. This type of edema involves, for the most part, the lower extremities, pits slightly on pressure and, like the first variety, is unaccompanied by any abnormalities of renal or cardiac function.

In a warm environment, as shown by Lewis and Pickering (14), the cutaneous vessels of the upper extremities dilate in order to promote loss of heat. Gibbon and Landis (15) found that immersing the forearms in warm water induces in the lower extremities a maximal vasodilatation which is comparable in degree to that obtained by spinal anesthesia. Under these conditions, the total area of capillary wall available for filtration in the extremities must be much increased. In the erect posture venous pressure in the lower extremities may reach very high levels due to the hydrostatic pressure of the column of venous blood. In the presence of such high venous pressure, an increase in the capillary area available for filtration would favor the accumulation of greater amounts of fluid in the tissue spaces. Heat edemas may, therefore, be at least partially due to physical effects similar to those exerted by local heat on the filtration of fluid through the normal capillary wall.

Observations on the filtration produced by continued venous congestion show that, beginning with the first minutes of congestion, some force diminishes the power of a given venous pressure to filter fluid from the blood into the tissue spaces. This might be due $(a)$ to a change in the membrane in the direction of decreased permeability, or $(b)$ to some force in the tissue spaces opposing capillary pressure. As evidence that the 
first possibility cannot explain the findings it may be mentioned that when venous pressure was elevated for two periods of ten minutes each, the rate of filtration during the second period was always less than that during the first. Then if the fluid was allowed to leave the forearm and the determination was repeated, using the same venous pressure, the filtration during the third period of ten minutes was approximately the same as that observed during the first period. Moreover, the decrease in filtration rate depended quite definitely (Figure 8) on the amount of fluid in the tissue spaces.

Krogh, Landis and Turner (1) observed that an accumulation of fluid in the tissue spaces diminished or even abolished the power of venous pressures of 15 to $30 \mathrm{~cm}$. water to produce filtration. Lymphatic drainage and tissue pressure were both considered in the discussion of these results but the limitations of the earlier method precluded any definite decision concerning the relative importance of these two factors.

From the observations reported in this paper it appears that tissue pressure is the more important. Filtration rates measured during the first period of congestion were uniformly higher than those in succeeding periods even when the armlet was inflated continuously during the time when "reduced arm volume" was measured (Table 2, first four experiments). Under these conditions lymph could leave the arm only if pressure in the lymphatic vessels exceeded the pressure in the armlet. The change in "reduced arm volume" produced by prolonged periods of venous congestion amounting to 20 or $30 \mathrm{~cm}$. water was not significantly changed by thus preventing the complete emptying of the lymphatics during each determination of "reduced arm volume."

Drury and Jones (2) found that at a given venous pressure the rate of filtration between the tenth and twentieth minutes of congestion was greater than that between the twentieth and thirtieth minutes. They were, however, unable to measure the volume of fluid filtered during the first ten minutes of congestion; this explains in part the relatively low filtration rates reported in their paper.

The rates of filtration observed in the forearm during the first ten minutes of venous congestion were higher than those observed during the first 30 minutes of venous congestion (Figures 2 and 3). This difference must be related to the rapid decrease in the rate of filtration observed during long continued venous congestion (Figure 6). The observations are in accord with the conception that, as fluid accumulates in the tissue spaces, an increasing pressure is required to overcome the elasticity of the separated tissue elements. This tissue pressure becomes greater as the volume of extravascular fluid increases and, since it opposes the filtering pressure within the capillaries, makes itself evident in the diminished rates of filtration produced by any given venous pressure (Figures 6,7 and 8).

The tissue pressure developed by the accumulation of small amounts of 
fluid in the normal forearm can be estimated indirectly by observing the amount by which filtration is reduced. When filtration is measured through periods of ten minutes, a change in venous pressure of $10 \mathrm{~cm}$. water modified the rate of filtration by $.033 \mathrm{cc}$. per minute per $100 \mathrm{cc}$. of arm (Figure 3). As shown in Figure 8 when the filtered fluid amounted to $1.0 \mathrm{cc}$. per $100 \mathrm{cc}$. of arm, filtration was decreased approximately $.033 \mathrm{cc}$. per minute per $100 \mathrm{cc}$. of arm-a change which corresponds to the effect of lowering venous pressure by $10 \mathrm{~cm}$. water. When the filtered fluid amounted to $5.0 \mathrm{cc}$. per $100 \mathrm{cc}$. of arm the filtration was reduced by approximately $.110 \mathrm{cc}$. per minute per $100 \mathrm{cc}$. of arm-a change which corresponds to the effect of lowering venous pressure by $35 \mathrm{~cm}$. water. It is obvious that absolute figures for tissue pressure thus indirectly obtained cannot have great significance until they have been verified by some more direct method.

The first and apparently the only attempt to estimate tissue pressure directly was that of Landerer (16), who introduced a fine needle or cannula into the cutaneous and subcutaneous tissues in order to determine the pressure which was required to force small amounts of fluid slowly into the tissue spaces. He concluded that in rabbits the tissue pressure is normally about 5 to $7 \mathrm{~cm}$. water, but varies widely in different tissues. $\mathrm{He}$ found also that venous congestion elevated tissue pressure conspicuously, but mentioned neither the duration nor the grade of the venous congestion. Various measurements of skin tension have been made by means of the elastometer (Schade (17), Kunde (18)) but these provide no information concerning absolute tissue pressures.

It would appear, however, that in the human being tissue pressure may be one of the most important factors in maintaining normal blood volume against considerable hydrostatic disadvantage. Adolph (19) has suggested that in the observations of Krogh, Landis and Turner (1) venous pressures below $17 \mathrm{~cm}$. water failed to produce measurable filtration because of tissue pressure. Thompson, Thompson and Dailey (20) and Waterfield (21) observed that blood volume decreased rapidly during the first 30 minutes of quiet standing after which period no further change in blood volume could be observed. Reference to Figure 6 will show that it is during the first 30 minutes of venous congestion that the greatest decrease in filtration occurs.

The physiological significance of this mechanism is obvious. One of the greatest difficulties in applying the Starling hypothesis to problems of fluid balance in man has been the absence of local edema in the dependent parts of normal individuals. In the lower extremities the excess of venous and capillary pressure over colloid osmotic pressure should, if Starling's two factors were the only ones concerned, produce a considerable grade of local ankle edema. During quiet standing fluid is lost from the blood, as shown by Thompson, Thompson and Dailey (20) but the loss ceases before edema appears. 
The dangers of reducing blood volume too greatly are obvious. Quiet standing brings the vascular system quite near to complete failure and resultant syncope as shown by Turner, Newton and Haynes (22) and by Hamilton, Lichty and Pitts (23). Any mechanism which limits the amount of fluid which is lost to the tissue spaces will significantly reduce the need for cardiovascular readjustments in prolonged standing.

The occurrence of edema shows in itself, however, that the power of tissues to resist the accumulation of tissue fluid is a limited one. Landerer believed that all forms of edema could be explained by the diminished elasticity of the edematous tissue. But in determining the modulus of normal and edematous tissues he failed to take into the account that a given mass of edematous tissue contains fewer connective tissue fibers and more fluid than the same volume of normal tissue. It would be expected, therefore, that under a given force edematous tissue would stretch more. Bönninger (24), in testing the elasticity of the skin in cadavers, found no evidence that the elasticity of tissue was diminished in edema. The skin removed from an edematous extremity shortened more than did skin taken from a normal extremity. Bönninger found, however, that the tissues are very imperfectly elastic and when stretched even slightly they gradually elongate, failing to return to their original length when tension is removed. Therefore, a relatively low tissue pressure acting for a long time might gradually stretch the tissue, the elasticity of which could delay, but could not prevent, the appearance of edema.

No measurements of tissue pressure in edema are available. The tightness of the skin in massive edemas suggests that the tissue pressure may be quite high under certain conditions. It is a clinical truism that certain forms of edema appear first in the loose tissues of the orbit and face. Yet the looseness of tissue is not the primary cause for the appearance of the edema, since, as Fishberg remarks (25), the relaxed abdominal skin of multiparae is not usually edematous.

In considering the movement of fluid through the capillary wall the factors of first importance are capillary pressure, the colloid osmotic pressure of the blood, and the permeability of the capillary wall. Two important subsidiary physical factors, temperature and tissue pressure, must be kept in mind since they can modify the effects produced by a given difference between capillary pressure and colloid osmotic pressure.

\section{SUMMARY}

A pressure plethysmograph was arranged so that each determination of "reduced arm volume" (i.e. tissue volume with the blood vessels collapsed) required only two minutes' stoppage of blood flow. The apparatus could be kept at a temperature constant within $1^{\circ} \mathrm{C}$. It was shown that measurements of "reduced arm volume" were relatively independent of the variations in arm volume produced by vasomotor 
changes or by simple engorgement of the veins. During two-minute periods of $200 \mathrm{~mm}$. $\mathrm{Hg}$ pressure the plethysmograph expressed only negligible quantities of fluid from the segment of forearm enclosed within it.

The movement of fluid through the human capillary wall was studied in relation to venous pressure, temperature and duration of venous congestion. It was found that above an average venous pressure of 12 $\mathrm{cm}$. water the rate of filtration was directly proportional to the increase in venous pressure. A unit rise in venous pressure $(1 \mathrm{~cm}$. water) increased the filtration rate by $.0028 \mathrm{cc}$. per minute per $100 \mathrm{cc}$. of forearm when the congestion periods were 30 minutes long and by $.0033 \mathrm{cc}$. per minute per $100 \mathrm{cc}$. of forearm when the congestion periods were 10 minutes long.

The temperature of the forearm exerted a conspicuous effect on the rates of filtration produced by given venous pressures. In general, the rates of filtration produced by venous pressures of $30,40,50$ and $60 \mathrm{~cm}$. water with a forearm temperature of 44 to $45^{\circ} \mathrm{C}$. were almost twice as great as those produced by the same pressures with a forearm temperature of 14 to $15^{\circ} \mathrm{C}$.

The rate of filtration produced by any given venous pressure decreased rapidly as fluid accumulated in the tissue spaces. The filtration rate was reduced most rapidly during the first 30 minutes of venous congestion. When sufficient fluid had accumulated in the tissue spaces low venous pressures failed to produce further filtration. With large accumulations of fluid in the tissue spaces the filtration rate was decreased by an amount which was equivalent to a tissue pressure as high as $35 \mathrm{~cm}$. water.

The importance of these two factors, temperature and tissue pressure, is briefly discussed with reference to normal fluid balance and to the formation of edema.

\section{BIBLIOGRAPHY}

1. Krogh, A., Landis, E. M., and Turner, A. H., J. Clin. Invest., 1932, xi, 63. The Movement of Fluid through the Human Capillary Wall in Relation to Venous Pressure and to the Colloid Osmotic Pressure of the Blood.

2. Drury, A. N., and Jones, N. W., Heart, 1927, xiv, 55. Observations upon the Rate at Which Oedema Forms When the Veins of the Human Limb are Congested.

3. Lewis, T., and Grant, R., Heart, 1925, xii, 73. Observations upon Reactive Hyperemia in Man.

4. Bazett, H. C., Physiol. Rev., 1927, vii, 531. Physiological Responses to Heat.

5. Okuneff, N., Arch. f. d. ges. Physiol., 1924, cciv, 261. Über den Einfluss lokaler thermischer Reize auf die Abwanderung eines intravenös injizierten kolloidalen Farbstoffs aus dem Blute.

6. Lewis, T., and Haynal, I., Heart, 1928, xiv, 177. Observations Relating to the Tone of the Minute Vessels of the Human Skin; with Remarks upon and Illustrations of Measurement of Pressure within These Vessels. 
7. Landis, E. M., Heart, 1930, xv, 209. Micro-injection Studies of Capillary Blood Pressure in Human Skin.

8. Hamilton, W. F., and Barbour, H. G., Am. J. Physiol., 1925, lxxiii, 321. Heat Regulation and Water Exchange. VIII. The Fate of the Fluid Leaving the Blood in Cold Anhydremia.

9. Barbour, H. G., and Hamilton, W. F., Am. J. Physiol., 1925, lxxiii, 665. Heat Regulation and Water Exchange. IX. The Mechanism of Cold Anhydremia and Edema.

10. Lewis, T., Heart, 1930, xv, 177. Observations upon the Reactions of the Vessels of the Human Skin to Cold.

11. Barcroft, J., and Kato, T., Phil. Tr. Roy. Soc., Lond., B, 1916, ccvii, 149. Effects of Functional Activity in Striated Muscle and the Submaxillary Gland.

12. Asher, L., and Barbèra, A. G., Ztschr. f. Biol., 1898, xxxvi, 154 . Untersuchungen über die Eigenschaften und die Entstehung der Lymphe.

13. Castellani, A., Tr. Roy. Soc. Trop. Med. and Hyg., 1931, xxiv, 379. Minor Tropical Diseases.

14. Lewis, T., and Pickering, G. W., Heart, 1931, xvi, 32. Vasodilatation in the Limbs in Response to Warming the Body; with Evidence for Sympathetic Vasodilator Nerves in Man.

15. Gibbon, J. H., Jr., and Landis, E. M., J. Clin. Invest., 1932, xi, 1019. Vasodilatation in the Lower Extremities in Response to Immersing the Forearms in Warm Water.

16. Landerer, A., Die Gewebspannung in ihren Einfluss auf die örtliche Blutund Lymph-bewegung. Leipzig, 1884.

17. Schade, H., München. med. Wchnschr., 1926, 1xxiii, 2241. Gewebselastrometrie $\mathrm{zu}$ klinischen und allgemeinärztlichem Gebrauch.

18. Kunde, M. M., Arch. Int. Med., 1926, xxxviii, 57. Edema. I. Correlation of Elastometer Findings, Disappearance Time for Intradermally Injected Salt Solution, Urinalysis and Nitrogen Retention of the Blood in Edema.

19. Adolph, E. F. (Personal communication).

20. Thompson, W. O., Thompson, P. K., and Dailey, M. E., J. Clin. Invest., 1927, v, 573. The Effect of Posture upon the Composition and Volume of the Blood in Man.

21. Waterfield, R. L., J. Physiol., 1931, lxxii, 110. The Effects of Posture on the Circulating Blood Volume.

22. Turner, A. H., Newton, M. I., and Haynes, F. W., Am. J. Physiol., 1930, xciv, 507. The Circulatory Reaction to Gravity in Healthy Young Women.

23. Hamilton, J. E., Lichty, J. S., and Pitts, W. R., Am. J. Physiol., 1932, c, 383. Cardiovascular Response of Healthy Young Men to Postural Variations at Varied Temperatures.

24. Bönninger, M., Ztschr. f. exper. Path. u. Therap., 1905, i, 163. Die elastische Spannung der Haut und deren Bezeihung zum Oedem.

25. Fishberg, A. M., Hypertension and Nephritis. New York, 1930. 